\title{
The Late Holocene evolution of the Black Sea - a critical view on the so- called Phanagorian regression
}

\author{
Eric Fouache ${ }^{\mathrm{a},{ }^{*}}$, Daniel Kelterbaum ${ }^{\mathrm{b}}$, Helmut Brückner ${ }^{\mathrm{b}}$, Gilles Lericolais ${ }^{\mathrm{c}}$, \\ Alexey Porotov ${ }^{d}$, Vassily Dikarev ${ }^{d}$ \\ ${ }^{a}$ University of Paris-Ouest-Nanterre-La Défense, IUF, EA 375 GECKO and UMR 8591 Laboratoire de \\ Géographie physique, 200 Avenue de la République, 92001 Nanterre CEDEX, France \\ ${ }^{\mathrm{b}}$ Department of Geography, Universität zu Köln, Albertus-Magnus-Platz, 50923 Köln, Germany \\ c IFREMER - Centre de Brest, Géosciences Marines - BP 70, F-29280 Plouzane cedex, FRANCE \\ d Moscow State University, Geography Faculty, 119991, Moscow, GSP-1, 1 Leninskiye Gory, Russia \\ *: Corresponding author : eric.g.fouache@wanadoo.fr
}

\begin{abstract}
:
Throughout its geologic history, the Black Sea experienced major sea level changes accompanied by severe environmental modifications, including geomorphologic reshaping. The most spectacular changes were driven by the Quaternary glaciations and deglaciations that reflect responses to Milankovitch cycles of 100 and 20 ky periodicity. Major sea level changes were also considered for a shorter and more recent cyclicity. The concept of the Phanagorian re- and transgression cycle, supposedly with a minimum sea level stand of 5-6 $\mathrm{m}$ below its present position in the middle of the 1st millennium BC, was established in 1963 by Fedorov for the Black Sea region. It was based on archaeological and palaeogeographical research conducted around the ancient Greek colonies of the Cimmerian Bosporus, in particular at the name giving site of Phanagoria, where underwater prospection had revealed the presence of a large number of submerged relics of the Classical Greek era.

Analyses of sediment cores as well as 14C-dated fossil coastal bars in the western and southern parts of Taman Peninsula show that contemporary coastal bars are related to different sea levels. The dissymmetry can reach up to $6 \mathrm{~m}$ around $500 \mathrm{BC}$. This and more evidence from drill cores confirms that on Taman Peninsula many of the apparent sea level changes are tectonically induced. The subsidence may have been initiated by the release of gas from mud volcanoes inherited along anticline axes. Other observations around the Black Sea confirm that submerged archaeological sites correspond to areas where subsidence has taken places, while the so-called Holocene highstand said to have been located above the present-day sea level - is associated with uplift areas (triggered by the ongoing Caucasus orogeny). Recent oceanographic research carried out in the Black Sea area shows that since the Black Sea was reconnected with the Mediterranean Sea (i.e., 7500 14C BP at the latest), both marine water bodies have been in equilibrium. This fact and arguments from archaeology, history, hydrodynamics etc. lead us to question the existence of the Phanagorian regression. It is important to note that none of the sea level curves established for the (eastern) Mediterranean shows a comparable regression/transgression cycle of several metres during the 1st millennium BC.
\end{abstract}

Keywords: Black Sea, Phanagorian regression, geoarchaeology, tectonics, Taman Peninsula 


\title{
The Late Holocene evolution of the Black Sea - a critical view on the so-called Phanagorian regression
}

\author{
Eric Fouache $^{\mathrm{a}}$, Daniel Kelterbaum ${ }^{\mathrm{b}}$, Helmut Brückner ${ }^{\mathrm{b}}$, Gilles Lericolais ${ }^{\mathrm{c}}$, Alexey Porotov ${ }^{\mathrm{d}}$, \\ Vassily Dikarev \\ a University of Paris-Ouest-Nanterre-La Défense, IUF, EA 375 GECKO and UMR 8591 Laboratoire de \\ Géographie physique, 200 Avenue de la République, 92001 Nanterre CEDEX, France \\ b Department of Geography, Universität zu Köln, Albertus-Magnus-Platz, 50923 Köln, Germany \\ c, IFREMER - Centre de Brest, Géosciences Marines - BP 70, F-29280 Plouzane cedex, FRANCE \\ d Moscow State University, Geography Faculty, 119991, Moscow, GSP-1, 1 Leninskiye Gory, Russia
}

\begin{abstract}
Throughout its geologic history, the Black Sea experienced major sea level changes accompanied by severe environmental modifications, including geomorphologic reshaping. The most spectacular changes were driven by the Quaternary glaciations and deglaciations that reflect responses to Milankovitch cycles of 100 and 20 ky periodicity. Major sea level changes were also considered for a shorter and more recent cyclicity. Actually, the concept of the Phanagorian re- and transgression cycle, supposedly with a minimum sea-level stand of 5$6 \mathrm{~m}$ below its present position in the middle of the $1^{\text {st }}$ millennium BC, was established in 1963 (Fedorov 1963) for the Black Sea region. It was based on archaeological and palaeogeographical research conducted around the ancient Greek colonies of the Cimmerian Bosporus, in particular at the name giving site of Phanagoria, where underwater prospection had revealed the presence of a large number of submerged relics of the Classical Greek era.

Analyses of sediment cores as well as ${ }^{14} \mathrm{C}$-dated fossil coastal bars in the western and southern parts of Taman Peninsula show that contemporary coastal bar are related to differents sea levels. The dissymmetry can reach up to $6 \mathrm{~m}$ around $500 \mathrm{y} \mathrm{BC}$. This and more evidence from drill cores confirms that on Taman Peninsula many of the apparent sea level changes are tectonically induced. The subsidence may have been initiated by the release of gas from mud volcanoes inherited along anticline axes. Also other observations around the Black Sea confirm that submerged archaeological sites correspond to areas where subsidence has taken places, while the so-called Holocene highstand - said to have been located above the present day sea level - is associated with uplift areas (triggered by the ongoing Caucasus orogeny). Recent oceanographic research carried out in the Black Sea area shows that since the Black Sea was reconnected with the Mediterranean Sea (i.e., $7500{ }^{14} \mathrm{C}$ BP for the latest), both marine water-bodies have been in equilibrium. This fact and arguments from archaeology, history, hydrodynamics etc. lead us to question the existence of the Phanagorian regression. It is important to note that none of the sea level curves established for the (eastern) Mediterranean shows a comparable regression/transgression cycle of several metres during the $1^{\text {st }}$ millennium BC.
\end{abstract}

Keywords : Black Sea, Phanagorian regression, geoarchaeology, tectonics, Taman Peninsula

\section{1 . Introduction and historical background}

The Black Sea is one of the largest enclosed seas in the world experiencing major sea level changes accompanied by severe environmental modifications. The most spectacular changes were driven by the Quaternary glaciations and deglaciations that reflect responses to Milankovitch cycles of $100 \mathrm{ky}$ (excentricity) and $20 \mathrm{ky}$ (precesion) periodicity. These sea level fluctuations endowed the restricted channels of the Bosporus and Dardanelles with the power to control the Black Sea's connection to the Mediterranean. When global sea level 
dropped below the Bosporus sill, water level in the Black Sea varied according to regional conditions independent of those in the world ocean. Perhaps the most important consequence of these lowstands was the interruption of Mediterranean inflow into the Black Sea, which, lacking any saline contribution, gradually became a giant brackish to freshwater lake (Panin and Popescu 2007; Soulet et al. 2010). The last 20 ky cycle of the Black Sea is probably one of the most puzzling cycle studied presently. Among others the sea level history of the Black Sea for the last eight millennia has been discussed in many publications (Nevessky 1967; Fedorov 1977; Dzhanelidze 1980; Balabanov \& Yzmailov 1988; Izmailov et al. 1989; Balabanov 2007 2009; Panin and Popescu 2007; etc.). The documented and/or postulated sea level changes reflect the general trends in the evolution of the basin and the regional peculiarities of the Holocene transgression.

Two principal patterns define the regional distinction between the Black Sea and others seas, e.g. the Mediterranean, which have been substantiated by Balabanov \& Izmailov (1988) and Balabanov (2007, 2009): the small magnitude of the tectonic deformation of the Holocene synchronous shorelines on the continental margin of the Black Sea, and short sea level fluctuations of several metres superimposed on the general transgression trend.

The first one provided a basis for the sea level curve for the Black Sea region. Its principal pattern and data base have been regarded recently by I. Balabanov $(2007 ; 2009)$. The second one is related to the trace of rhythmic fluctuations of the sea level which are identifiable in the sedimentary record and coastal geomorphology of the Black Sea littoral. Despite some evidence of such fluctuations for the past eight millennia, the number and amplitude of the intermediate regressions vary in different regions and are under discussion till now. Among these small-scale fluctuations of sea level, most attention was focused on the so-called "Phanagorian regression", supposedly reflecting a major sea level change in the middle of the $1^{\text {st }}$ millennium BC.

\section{The Phanagorian Regression}

The concept of the Phanagorian regression was established in 1963 when P. Fedorov published his thesis on the palaeogeographic evolution of the Black Sea region (Fedorov 1963). According to different sources Fedorov proposed the most probable level of the Black Sea in the middle of the $1^{\text {st }}$ millennium $\mathrm{BC}$ at a depth of 5-6 m below its present position (Fedorov 1977). This assumption was based on submerged archaeological remains in the Gulf of Taman, first noticed at the drowned lower city of Phanagoria. Phanagoria is known from written sources to have been founded by Greeks from Miletus (now in Turkey) around the $7^{\text {th }}$ century BC, same as Hermonassa, Kepoi and several other small settlements on Taman Peninsula (Paromov 2006; Zhuravlev et al. 2010). Today, the so-called lower city of Phanagoria is located in the Gulf of Taman at a depth of -2 to $0 \mathrm{~m}$ below present sea level (b.s.1.) (Fouache et al. 2000a, b, 2004).

Additionally, the assumed fall in sea level was supported by the presence of cultural layers of Late Bronze/Early Iron Age on the surface of middle Holocene beach ridges that were traced at different places of the Black Sea margin (Fedorov 1984). There are indeed other settlements on Taman Peninsula, some parts of which are nowadays submerged, e.g., Nymphaeum (Porotov 2006) and at Cape Panagia (Kondrashov 1995).

The problem was to interpret this phenomenon in the context of sea level evolution. In the scientific community of the former Soviet Union, only the concept of a lower sea level was 
taken into account for the time of the foundation of these ancient Greek settlements. Since, due to other findings, sea level was presumed to have been higher before that time, a major marine regression was presumed as being the most probable reason.

In the following decades the idea of a rapid sea level regression/transgression cycle during the $1^{\text {st }}$ millennium, with the lowest position around $500 \mathrm{BC}$ was perpetuated (Shilik $1975 \mathrm{a}, \mathrm{b}$, 1997; Balabanov1982; Balabanov \& Izmailov 1988; Izmailov et al. 1989; Shilik 1975a, b, 1997). While the principal concept as such was accepted in some parts of the scientific community, the only discrepancies were the chronology boundaries and the amplitude, as already pointed out by Porotov (2007). While 4-5 m below present sea-level is a medium value currently attributed to the Phanagorian regression, the values vary along the coasts of the Black Sea from $2 \mathrm{~m}$ via 3-4 $\mathrm{m}$ and 5-7 $\mathrm{m}$ up to 7-9 $\mathrm{m}$ b.s.l. and even more (e.g. Shilik 1975a, b; Krustev et al. 1990; see fig. 1).

The compilation in fig. 1 gives a detailed overview of different sea level curves developed for the Black Sea. It is obvious that there are major discrepancies between the authors concerning the shape of the curves. Nevertheless, all of them show a major regression/transgression cycle in the $1^{\text {st }}$ millennium BC, with a vertical sea level oscillation of up to $11 \mathrm{~m}$.

The existing assessments of the low position of the relative sea level during the so-called Phanagorian regression belonged to three principal types of sea level indicators: geomorphological, lithological and archaeological ones. This is well summarized by Balabanov (2009).

The extensive study of the Holocene sedimentary complex along all continental margins of the Black Sea reveals the wide distribution of peat bog facies with ${ }^{14} \mathrm{C}$-age estimates of 2.0$3.0 \mathrm{ka} \mathrm{BP}$ at/or below the present sea-level position; they lie upon coastal marine sands or liman (coastal lakes) silty clays. This swamp facies is often buried by a transgressive sedimentary sequence reflecting the increase of accommodation space in deltaic/lagoonal environments and the formation and shifting of a new generation of beach ridges on open marine coasts.

Several examples of late Holocene sedimentary sequences for the eastern part of the Black Sea coastline were studied by Balabanov (2009) with special attention to Pitius Peninsula, Imeretinka's lowland (southern outskirts of present-day Sochi) and the coastal region of Abchazia. There, the buried swamp/lagoon peat occurs at a depth of 2.5-4.5 $\mathrm{m}$ (up to $8 \mathrm{~m}$ ) below present sea level.

More accurate data about a possible drop in sea level during the $1^{\text {st }}$ millennium BC were recorded from the Colchis (Georgia). The review of ${ }^{14} \mathrm{C}$-dated relict peat layers in different swamp areas with regard to their present position does, however, not permit to accept a possible relative fall in sea level of more than 2-3 $\mathrm{m}$ (Dzhanelidze 2007). This estimation is in good agreement with previous conclusions about the possible change in sea level during the late Holocene on the eastern coasts of the Black Sea (Dzhanelidze 1980; Gorlov et al. 2004) despite of the existence of more extreme values of a sea-level fall during this period (Balabanov \& Gey 1981; Balabanov \& Gaprindashvili 1987, Balabanov \& Izmailov 1988; Nikonov 1997; and others).

Traces of the disruption of the generally trangressive sequence by superimposed sea level fluctuations have been revealed in the sedimentary structure of different locations along the 
north-western part of the Black Sea (Balandin \& Trashchuk 1982; Inozemtsev et al. 1984; Molodykh et al. 1984; Gozhik \& Novosel'sky 1989).

In contrast to this opinion several other studies on the topic that were recently published (e.g. Fouache et al. 2004; Giosan et al. 2006; Porotov 2007; Lericolais et al. 2007 and 2009; Brückner et al. 2010) question the concept of the Phanagorian regression.

\section{Geological and geomorphological setting}

The Taman Peninsula in south-western Russia is situated between the Black Sea in the south and the Sea of Azov in the north (Fig. 2). To the west the Strait of Kerch represents the border to Crimea (Ukraine). This small sea passage was called 'Cimmerian Bosporus' in Antiquity. Taman's topographic border to the east is formed by the recent delta plain of the Kuban (ancient name: Hypanis). Near Strelka the river is divided into an old southern branch which had once debouched into the Black Sea, and the present-day northern branch which flows into the Sea of Azov.

Geologically, the Taman Peninsula is made up of Miocene and Pliocene rocks which are in many parts covered by Pleistocene loess deposits. The basement mostly consists of clay, sand and occasionally limestone. Compression tectonics, induced by the Alpine orogeny, provoked the emergence of these rocks and their folding along anticlines and synclines (Shnyukov et al. 1981; Saintot \& Angelier 2000). The whole peninsula is fractioned into tectonic blocks with slightly differing vertical and horizontal movements. The current relief is a result of the ongoing tectonics as well as levelling processes (Blagovolin 1962; Blagovolin \& Pobedonostsev 1973).

Intensive neotectonic deformation is described in the Eastern Black Sea and around the Taman Peninsula (Fig 3) (Meisner et al. 2009). Significant subsidence of the Eastern Black Sea during the Pliocene-Quaternary is recorded from seismic profiling as well as fast growth of diapirs. Some of these diapirs, reflected in the seabed relief as swells, caused a significant reduction of the thickness of the Miocene strata. Such geomorphological features of mud volcano diapirism along the anticlinal axes (Shnyukov et al. 1981) produce up to $150 \mathrm{~m}$ high eruptive and sometimes destructive cones. As a whole, the landscape can be described as an undulating one, supplemented by several lagoons within the synclinal structures and mud volcanoes within the anticlinal structures.

The coastal geomorphology is dominated by wave action, showing typical features of a microtidal regime. In the only weakly consolidated bedrock, steep cliffs have formed due to strong abrasion, especially in the western part of the peninsula (fig. 4). Sea level rise during the last decades intensified the abrasion processes. Sand barriers and spits have been built up by the longshore currents; thus, nearly all of the former open marine embayments were transformed into lagoons (e.g., Akthanizovskaya Liman, Blagoweschenskaya Liman; see fig. 4), some of which are nowadays silted up due to sediment input by the prograding Kuban delta (Brückner et al. 2010).

\section{Methodology}

For this paper we compare our results from Taman Peninsula with data from other places in the Black Sea area. Over the last years we have carried out several corings in different geoarchives of the study area (fig. 2). Archival material collected at the end of the 1960s by 
E.N. Nevesky (1967) for the Russian Shirshov Institute of Oceanology was used as well. This material was kindly given to us by Professor L.A. Nevesky

\subsection{Corings}

The corings (fig. 2) were done with the percussion coring device Cobra 248 of Atlas Copco Co. using augerheads with diameters of 6,5 and $3.6 \mathrm{~cm}$, respectively. A maximum depth of $12 \mathrm{~m}$ below present surface (b.s.) was reached. The coring strategy was based on transects through nearshore geoarchives, chosen by field survey and supported by satellite image interpretation. Position and elevation of each coring site were measured by DGPS with a vertical resolution of less than $2 \mathrm{~cm}$ (Leica Geosystems Co.; Leica 530 SR). On site, the vibracores were studied for colour (MUNSELL Soil Color Charts), grain size, roundness and texture as well as for macrofaunal and -floral remains. Former fieldwork carried out by Nevesky (1967) was integrated.

Multi-proxy geochemical analyses were done in the laboratories of the Faculty of Geography at Philipps-Universität Marburg (Germany) to support the determination of facies changes (Vött et al. 2002, 2007). Combined with the grid of corings, the vertical and horizontal variations of the different milieus of deposition - marine, littoral, lagoonal, limnic, fluvial are the basis for the reconstruction of the palaeogeographic evolution and palaeo-sea level stands in the area of research.

In a geoarchaeological context, the proper calibration and dendrochronological correction of the radiocarbon ages plays a major role since at a given archaeological site, the ${ }^{14} \mathrm{C}$ age estimates have to be compatible with the chronologies provided by the archaeological and the historical sciences. In our case, we ${ }^{14} \mathrm{C}$-dated mollusc shells, plant remains and peat. The ages determined on mollusc shells were corrected for an average marine reservoir effect of 408 years. However, it has to be considered that the palaeo-reservoir effect is still unknown and may have varied widely in different marine environments, such as lagoons, coastal swamps or littoral zones, and as well in different seas (Mediterranean, Black Sea, the Sea of Azov). AMS ${ }^{14} \mathrm{C}$ dating of ostracod and gastropod shells from the southwestern Black Sea cores combined with tephrochronology suggest variable reservoir ages for the late glacial Black Sea basin from 0 to $1450 \mathrm{yr}$ (Kwiecen 2008, 2009). Fontugne et al. (2009) propose that chemoautotrophic productivity is contributing to the sedimentary organic matter explaining so the variation of reservoir ages evident during the Holocene in the anoxic Black Sea. Additionally, the discharge of river (Tab. 1) and their input of ${ }^{12} \mathrm{C}$ plays a role, especially in semi-enclosed basins, such as the Black and Azov Seas. The ${ }^{14} \mathrm{C}$ age estimates presented in this study were taken from those vibracores (see fig. 2) that contained the most reliable sea level indicators. All dates are calibrated ages in cal BC/AD [calibration with Calib 5.0.2; Reimer et al. (2004)]. The datings concerning the archival material of the Shirshov Institute of Oceanology collected in 1967 by Nevesky are integrated in the corings in the Gulf of Taman (see fig. 2, tabs. 2 and 3 )

\subsection{Sea level indicators}

Archaeological remnants in the Gulf of Taman can be used for the determination of a widespread submersion of the area since Late Antiquity (Abramov 1999; Blavatsky 1985). So far, however, we have been unable to find precise archaeological indicators, such as jetties and fishponds, on Taman Peninsula. It was also impossible to apply the methods proposed by Flemming (1979), Pirazzoli (1979), Morhange (2001) and by us in Turkey (Fouache et al. 
2000a) and Croatia (Fouache et al. 2000b) for the determination of the palaeo-sea level at a given time. Therefore, we focussed on (a) paralic peat layers and (b) the identification of shell assemblages, characteristic for thanatocoenosis fauna accumulated at a mean sea level and reflecting an average position of (palaeo-) sea level with an error margin of $\pm 1 \mathrm{~m}$ (this is why we prefer to use envelopes in our sea level curves). Extracted shell material was palaeoenvironmentally interpreted according to Kaplin et al. (2001) by T. Yanina at the Geographical Faculty of Moscow State University. Conventional radiocarbon dating was performed at the Geological Institute of the Russian Academy of Sciences and at the Geographical Faculty of Moscow State University, AMS $-{ }^{14} \mathrm{C}$ dating at the Center for Applied Isotope Studies (CAIS), University of Georgia, Athens GA (USA) (Tabs 2 and 3).

\section{Results - sea level curves from Taman Peninsula}

\subsection{Coring results and interpretation}

In this paper we compare our results obtained on Taman Peninsula with data of other places of the of Black Sea coast. We drilled several boreholes on the peninsula down to 12 meters b.s. (fig. 2). A first set consisted of six corings (S1 - S6): one in the Kuban delta (S1), one each on Burgaz Spit (S2) and Choushka Spit (S3), and three on Anapa Spit (S4, S5 and S6).

Coring S1 (fig. 2), located in the Kuban delta, contains peat at the base, then follow marine sediments of a semi-closed embayment topped by deltaic sediments (Fouache 2000a, b, 2004). Palynological analysis confirms that there was a marine environment during the Greek colonization (Bolikovskaya et al. 2004). The radiocarbon age of the basal peat (5940 \pm $50 \mathrm{BP}$, uncalibrated Age) shows that the maximum landward inundation of the sea occurred during that time. The other cores S2 - S6 show an alternation between sandy biodetritic sediment, characteristic of beaches, and mainly clayey sediments rich in shells, characteristic of open marine condition (S2 and S3 in fig. 2; S4 in fig. 2, S5 and S6 in fig. 2). The biggest palaeogeographical change since Antiquity has taken place in the Gulf of Taman, where most parts of the former city of Phanagoria is now submerged.

A second set of corings were carried out in the Kuban delta plain, the Golubitskaya sand spit system, the Soleni Liman and again on Anapa Spit. For detailed information concerning the palaeogeographical, geomorphological, sedimentological and environmental interpretation see, e.g., Brückner et al. (2010). As a typical example the coring profile DZHI 2 (see figs. 2 and 5) will be described in the following.

DZHI 2 was carried out in the lower delta plain of the Kuban, located near the bifurcation of the Kuban river in its northern and southern distributary branches (coring depth: $14 \mathrm{~m}$ b.s.; surface elevation: $1.20 \mathrm{~m}$ a.s.l.; position of coring site: $\left.45^{\circ} 11^{\prime} 20,8^{\prime}{ }^{\prime} \mathrm{N}, 37^{\circ} 24^{\prime} 55,5^{\prime \prime} \mathrm{E}\right)$. The lowermost section of the sediment column (12.80 - $11.10 \mathrm{~m}$ b.s.l.) consists of a silty sand. Geochemical parameters as well as thin section analyses show a high content of organic matter and sulphide, and no marine macro- nor microfauna, which hints to a fluvial environment. Then follows a transgressive peat $(11.10-10.17 \mathrm{~m}$ b.s.l.) which started to grow 5533 - 5381 cal BC and ended $~ 800$ years later (4769 - 4549 cal BC). Such a paralic peat represents the former sea level; it is, therefore, an excellent sea level indicator. The peat is covered by bluish grey clayey silts, slightly enriched in calcium carbonate; they were deposited under open marine conditions. At a depth of $7.30 \mathrm{~m}$ b.s.l. a shell hash layer (among others Cerastoderma glaucum) was dated to 3289 - 2949 cal BC. Within the given sedimentary context this age documents the continued marine environment and a water depth of several meters. The fully marine facies end half a metre higher at $6.80 \mathrm{~m}$ b.s.l. with the first occurrence of laminae of fine sands. Up to $3.08 \mathrm{~m}$ b.s.l. their thickness grows. They contain 
small pebbles of reddish silty clay, formed and transported by wave dynamics; features like that can still be found on the shores of Taman Peninsula that are bordered by active cliffs (see fig. 4). This reflects an environmental change from a marine to a littoral or lagoonal milieu. Another hint for this definite change is the fact that the Anapa Spit was fully evolved at the beginning of the $2^{\text {nd }}$ millennium BC, cutting off the study site from the open Black Sea (Fouache et al. 2004, Izmailov 2007, Brückner et al. 2010). The same holds true for the Golubitskaya sand spit system in the north of Taman Peninsula, separating the former embayment from the Sea of Azov.

At a depth of $3.08 \mathrm{~m}$ b.s.l. the sedimentation changed dramatically to a graded bedding of nearly $1 \mathrm{~m}$ thickness. In the lowermost part of this stratum at $3.00 \mathrm{~m}$ b.s.l., mollusc shells dating to the $4^{\text {th }}-6^{\text {th }}$ centuries $\mathrm{AD}(351-591 \mathrm{cal} \mathrm{AD})$ represent another sea level indicator. It can be assumed that this material was deposited when the Kuban was nearby the site and debouched into the embayment, thus cutting off a small brackish lagoon with one of its distributaries. The lagoon is terminated by the formation of a paralic peat at $2.10 \mathrm{~m}$ b.s.l., dated to $979-1117 \mathrm{cal}$ AD. The fact that this peat is $2.10 \mathrm{~m}$ b.s.l. can best be explained by later tectonic subsidence. It is known that earthquakes have occurred occasionally in this region (Nikonov 1994).

The uppermost three metres ( $2.10 \mathrm{~m}$ b.s.l. $-1.20 \mathrm{~m}$ a.s.1.) are represented by brownish silt and sand layers reflecting flood events of the Kuban. A peat from an oxbow of the meandering river at $0.50 \mathrm{~m}$ b.s.l., dated to $1495-1650 \mathrm{cal} \mathrm{AD}$, is another possible sea level indicator since it formed only slightly higher than the palaeo-sea level.

Overall, the upper sediment column represents the typical stratigraphy of a river-dominated delta front after Battacharya \& Walker (1992). It is vertically enlarged by the total subsidence of the area and the compaction of the deposited peat which results in a higher sedimentation. If one takes into account both factors, most of the ${ }^{14} \mathrm{C}$ age estimates can be used for the reconstruction of the former sea level positions shown in fig. 5 .

\subsection{Sea level curves}

Following the coherence of our dating results - the deeper the shell or peat in the sedimentary column, the older the radiocarbon age - it is possible to reconstruct locally valid sea-level curves. When taking a closer look at several areas of Taman Peninsula it becomes obvious that each one has its own relative sea level curve: there is one for the Kuban delta plain (DZHI), another one for the Golubitskaya sandbarrier (GOL) and a third one for Semebratnee (SEM) (fig. 6, left side). The same holds true for the curves, focussing on sand spits (Anapa Spit and Burgaz Spit) and the Gulf of Taman (fig. 6, right side). A synoptic view shows that the differences can best be interpreted by differential tectonics and compaction.

When we look at the right side of fig. 6, we can distinguish two clusters with rather similar curves: Burgaz Spit and western Anapa Spit (S2 and S4) on the one hand, Choushka Spit (S3), and the eastern part of Anapa Spit (S5) on the other. The Gulf of Taman is a transition zone between these two areas. We can also identify a dissymmetry between contemporaneous sea levels. For example, in $1000 \mathrm{BC}$ sea level is located around $-2 \mathrm{~m}$ below its present position in $\mathrm{S} 5$, around $-4 \mathrm{~m}$ in $\mathrm{S} 3$ and around $-9.5 \mathrm{~m}$ in $\mathrm{S} 2$ and $\mathrm{S} 4$.

\subsection{Sea level curves and neotectonics}


When comparing the curves of fig. 6 it is interesting to note that the sites of Golubitskaya and Soleni from the central Taman area show a very similar sea level trend for the last seven millennia. On the other hand the estimated sea level band for the Kuban deltaplain (DZHI curve) is different, showing a steeper gradient. This may be the effect of compaction of the delta sediments. In addition there are good arguments that tectonics plays a definite role in the central part of the active Kuban graben structure. In contrast, the central Taman Peninsula is tectonically relatively stable.

\section{Points of criticism concerning major regressions of the Black and Azov Seas during the last 7 millennia}

Recent advances in Holocene sea level studies about the connection between the Black Sea and the Mediterranean via the Bosporus Strait make us question the whole concept of the socalled Phanagorian regression.

When comparing sea-level curves from the Mediterranean (fig. 7 with the Balabanov curve (included in fig. 1) it is striking that none of the Mediterranean curves shows the Phanagorian wiggle, a fact already outlined by Brückner et al. (2010). Could it be that both seas react totally differently although they have been connected at least since $7.5 \mathrm{ka}$ BP? Did all the researchers working in the (Eastern) Mediterranean, and especially in the Aegean Sea, miss the strong regression/transgression cycle during the $1^{\text {st }}$ millennium $\mathrm{BC}$ ? This seems very unlikely. Plus, there is no report from any of the Aegean coastal cities that they could not use their harbours anymore because of a major drop in sea level in the $1^{\text {st }}$ half of the $1^{\text {st }}$ millennium BC. The examples of Miletus (Brückner et al. 2006) and Ephesus (Kraft et al. 2007) are only two of many that could be listed here.

In addition to the results from our drillings carried out on Taman Peninsula (see chapter 5), none of which shows any evidence for the Phanagorian regression, there are several other facts and considerations why the idea of a major regression/transgression fluctuation of the Black Sea level during the $1^{\text {st }}$ millennium BC did not happen.

\subsection{Arguments from hydrodynamics}

There is a principal problem of a fall and a subsequent rise in the level of the Black and Azov seas for 7 or so metres within 400 years. Which hydrodynamic or climatic factor would be a plausible mechanism for such a scenario? A major lowering of sea level might only happen if evaporation definitely exceeded the combination of areal precipitation, river discharge into the Black Sea basin and an inflow from the Mediterranean. The opposite should be the case during the following phase of the refilling of the basin, with precipitation etc. definitely exceeding evaporation. However, no major climatic fluctuation has been reported by ancient Greek or Roman authors that would substantiate such an assumption. Plus, the climatic models do not support a major climatic change around $500 \mathrm{BC}$.

There is some evidence of solar insolation modifications during the time of the so-called Phanagorian regression which might be used for sea level lowering in a global sense (Mayewski et al. 2004). However, those insolation differences cannot be responsible for more than $0.5 \mathrm{~m}$ of water level modification and have a limited action in the Black Sea.

Moreover, since the Black and Azov seas have been connected with the Mediterranean and thus with the Atlantic Ocean - i.e. at least since $7.5 \mathrm{ka}$ or, even more likely, since $8.4 \mathrm{ka}$ BP 
(see inserted box) - the three seas have acted as communicating water bodies. Therefore, a drop in sea level of 7 or so metres in the Black Sea could not have remained there for decades or centuries. It would have been filled by the tributary rivers and the inflow from the Mediterranean via the Bosporus Strait.

\section{EXTRA BOX}

Since the publication of the book "Noah's flood" by Pitmann \& Ryan (1998), the scientific community has been divided into three parties: (1) those supporting the catastrophic reunion of both seas around $7500{ }^{14} \mathrm{C} \mathrm{BP}$ (Ryan et al. 1997, Pitman \& Ryan 1998, Ballard et al. 2000, Govedarica 2003), later corrected in between 8400 to 9000 BP (Ryan 2007; Lericolais et al. 2007, 2009 and 2010; Marret et al. 2009); (2) those rejecting the lowstand of the Black Sea and favouring a rise in sea level, (2a) either a gradual one (Aksu et al.1999, 2002a, b, Hiscott et al. 2002, Kaminski et al. 2002), or (2b) an oscillating one (Chepalyga 2002, 2007, Balabanov 2007, 2009, Glebov \& Shel'ting 2007, Konikov 2007, Yanko-Hombach 2007). Siddal et al. (2004) calculated that the Black Sea should be filled up in 34 yrs using scenario (1). Sperling et al. (2003) demonstrated that Sapropel deposition in the Marmara Sea suggest absence of low salinity water from the Black Sea during S1. Even though the Sapropel deposition in the Black Sea is not sudden and started when the Black Sea anoxia was established (I.E. after 7500 BP), Thom (2010) tried to calibrate a hydrological model but the model is unable to support the observed sudden onset of sapropel formation in the Black Sea in 7.6 ky BP together with arrival of Mediterranean Fauna. But in any case it is consensus that since 7500 BP (or 8400 cal BP) the Black Sea and the Mediterranean Sea have been connected. Therefore, the two marine water bodies should have been in equilibrium since then (Brückner et al. 2010). This being the case, it is difficult - or, as we think, impossible - to explain that oscillations of several meters took place in one sea that lasted for a couple of centuries (such as the so-called Phanagorian regression), but did not affect the other sea. Seasonal and short time differences of a few decimetres can easily be explained by exceptional inflow from the major rivers Danube, Dniepr, Don etc.

Assuming that during the $1^{\text {st }}$ millennium BC sea level of the Mediterranean was about $2 \mathrm{~m}$ below its present position as several of the relevant sea level curves suggest (fig. 7) there would still have been an altitudinal difference of $5 \mathrm{~m}$. If so, a strong inflow from the Mediterranean through the Dardanelles (Canakkale Strait), the Sea of Marmara and the Bosporus with a relatively high speed would have evolved in order to equalize the differences in the water columns.

Such a northbound current has never been reported. On the contrary: since the connection of the seas, there has always been a surplus of water in the Black Sea basin as compared to the Aegean Sea, causing an outflow from the Black Sea into the Mediterranean - a fact which was very well known to the sailors in ancient times. When, for example, the Greeks from the mother town of Miletus (now in Western Turkey) wanted to visit their many colonies in the Black Sea region during Archaic times $\left(7^{\text {th }}-6^{\text {th }}\right.$ centuries BC), the major obstacle was the westbound surface current in the Bosporus and the Canakkale Strait (Hellespont). Since during that time it was not possible to sail against the wind, the obstacle could only be overcome by rowing, towing, sailing with westerly winds and/or using drift anchors: baskets filled with stones were sunken into the eastbound saline bottom counter-current, thus helping to drag the ship eastwards. 
Another argument against the Phanagorian regression is the fact that a major difference in water levels between the Black Sea and the Aegean Sea (Mediterranean Sea) would have been equalized in only a couple of years; it would definitely not have remained for centuries.

Let us assume that during the peak of the Phanagorian regression $\sim 500 \mathrm{BC}$ the sea level difference was $5 \mathrm{~m} \mathrm{[-7} \mathrm{m}$ in the Black Sea and $-2 \mathrm{~m}$ in the Aegean Sea]. With the surface area of the Black Sea and the Sea of Azov being $475,000 \mathrm{~km}^{2}$ (Tolmazin 1985), a water volume of $2375 \mathrm{~km}^{3}$ had to be filled.

The major rivers tributary to the Black Sea basin are (in order of importance): Danube, Dnieper, Don, Rioni, Dniester, Kuban, Kizilyirmak, Sakarya, Southern Bug etc. Their average annual discharge at gauge stations close to their mouths is shown in tab. 1. The cumulated minimum annual discharge values sum up to $\sim 194 \mathrm{~km}^{3}$. Even for this worst case scenario, the water deficit would be balanced within 12.2 years (de facto it would be faster since then inflow from the Mediterranean speeded up the refilling process). With the best case scenario maximum values sum up to $\sim 512 \mathrm{~km}^{3} / \mathrm{yr}$ - only 4.6 years were needed for the restoration of the equilibrium. After Tolmazin (1985) the average value of the total river runoff directed towards the Black Sea basin is $\sim 350 \mathrm{~km}^{3} / \mathrm{a}$. In this case the deficit would be finished after 6.8 years.

For the calculations above precipitation and evaporation on the one hand, and a potential inflow of water from the Aegean Sea via the Bosporus were not taken into account. It is reasonable to assume that the contribution of these factors would equalize the difference in sea level even faster.

The essence of these reflections and calculations is the following: a major disequilibrium in the levels of the Black Sea and the Aegean Sea will be balanced in a couple of years; it will definitely not persist for centuries. Therefore, if the Mediterranean curves - tested at many sites by many different researchers - are correct, then the Phanagorian regression/transgression wiggle is impossible.

\subsection{Arguments from archaeology and ancient historical accounts}

The lack of evidence from written sources is another argument that no strong sea level fluctuations have occurred during the $1^{\text {st }}$ millennium BC. Ancient writers would have noted such an event that would have affected all of the coasts and in particular the coastal settlements. However, the written sources remain silent. On the contrary: during the Greek colonization in the Archaic times $\left(7^{\text {th }}\right.$ and $6^{\text {th }}$ centuries BC) all coastal settlements were founded close to the position of the present shoreline and not several kilometres off the present coast. That in some cases parts of the ancient settlements are nowadays submerged hints to a later subsidence and/or the general sea-level rise since the time of their foundation which is also known from the Mediterranean.

In addition, the archaeological findings contradict a regression of 5 or so meters, followed by a transgression of the same amount within a couple of centuries. Had this been the case, then the coastal settlers would have had to re-locate again and again their harbour installations first seawards, then landwards. In areas with a shallow shelf, e.g. the whole Sea of Azov (maximum depth: $19 \mathrm{~m}$ ) and the Odessa shelf (Ukraine), but also in many parts of Taman Peninsula, a vertical drop in sea level for 5 or so metres would have caused a seaward shift in 
the coastline for several kilometres. This can neither be substantiated by archaeological evidence nor by any historical accounts.

\subsection{Arguments from geomorphological features}

An argument against a major drop in sea level during the Late Holocene is that there is neither a sedimentological nor a palaeo-pedological evidence - e.g. a major erosional disconformity or any kind of palaeosol - in our corings. Had there been a major regression that was followed by a transgression 400 or so years later, then definitely a palaeosol would have formed on the surfaces that had been exposed to subaerial weathering. Plus, this should definitely have created a prominent erosional disconformity.

Major geomorphological features on Taman Peninsula are recent and relict erosional cliffs (up to $50 \mathrm{~m}$ in height; see fig. 3). They are formed in easily erodible unconsolidated Neogene bedrock. At Hermonassa, Sudarev \& Chevelov (2010) calculated a cliff retreat of up to $20 \mathrm{~m}$ for the last century. Extrapolating this figure into the past, then several hundred meters have been eroded at some of the historic sites during the past 2 to 3 millennia. This may be one reason why in some cases archaeological remains are found offshore.

Others reasons why parts of some ancient coastal cities are submerged for a couple of metres is subsidence tectonics (Fouache et al. 2004; Brückner et al. 2010). This effect combined with the general sea level rise of 2 or so metres since the time of their foundation has led to the submergence of the Lower city of Phanagoreia and other cities around the Kimmerian Bosporus.

\section{7 . Discussion}

Previous studies on the Holocene evolution of the Black Sea level underestimated or did not consider at all the role of tectonics, in this case mostly subsidence tectonics. Our study presents for the first time relative sea level curves for different localities on Taman Peninsula for the last seven millennia. In particular we dealt with the problem of the so-called Phanagorian regression, a presumed drop in sea level of 5-7 $\mathrm{m}$ or even more in the middle of the $1^{\text {st }}$ millennium BC.

Several authors support the existence of this major regression/transgression cycle (e.g., Fedorov 1963, 1977; Balabanov \& Izmailov 1988; Balabanov 2009; Chepalyga 2002; etc.). They back their theory on old data collected during Soviet times in coastal lowlands and deltas of the Caucasus foreland and the Crimea as well as on archaeological data collected, e.g., in Olbia or the Kerch-Taman region. Their collected radiocarbon ages lack exactly measured coordinates and, what is worse, the exact altitude above (present) sea level at the studied sites. Plus, most of these authors used bulk samples by sieving the whole sediment from $0.3 \mathrm{~m}$ up to $1 \mathrm{~m}$ thickness of the sedimentary column, and then conventionally ${ }^{14} \mathrm{C}$-dated the sieved mollusc shells. This method does, however, not give any good age estimates since the time resolution is bad (it may integrate over several centuries); in addition, it does not refer to specific sea level indicators. Often the sedimentary context is not well described and therefore it is not easy to reconstruct the exact depositional position in relation to palaeo-sea level. This is discussed in detail by Brückner et al. (2010).

In the studied sediment columns it is interesting to note that peat layers - which are amongst the most valuable sea level indicators - occur as transgressional paralic peat layers and in the 
deltafront sediments of the Kuban River. Only the Semebratnee soite bears peat formations in the sediment column as intercalated layers (see Brückner et al. 2010). They can best be interpreted as marsh peats (Styan \& Bustin 1983) that formed in cut-off oxbows during delta progradation; later they are flooded by the still rising sea level and/or due to the changed direction of the estuary creeks. The evolution of these so-called "floating peats" is also explicable by the theory of small regression cycles which normally took place in subsiding areas (cf. Streif 1990 and 2004, North Sea; Sornoza et al. 1998, Ebro delta, Spain; Vött 2007, Acheloos delta, Greece; Coleman et al. 1998, Mississippi delta).

Another point of critique, concerning the existence of the Phanagorian regression, is the lack of erosional unconformities in the sediment column. They should be traceable if sea level had dropped by several metres, thus initiating erosion by water and weathering under aerial conditions. In none of the coring stratigraphy on Taman Peninsula did we find hints for erosional dicordances, staining of the sediment, incisions of former estuaries of the Kuban river, etc. In addition, if after the formation of a peat layer a major regression occurred, the peat would have decayed and weathered. Consequently, its colour and texture would definitely have changed. However, this cannot be observed. Hence, only a minimal local regression of sea level has to be considered for the time of the peat formation (e.g. Sornoza et al. 1998) which can be easily initiated by the tectonic subsidence tendency in the Kuban graben structure.

Compared to the curves of Golubitskaya and Semebratnee, the one of the Kuban river delta plain shows a steeper gradient (fig. 6). The reasons may be compaction of the deltaĩc sediments and subsidence. In fact, the tectonic factor (mostly subsidence) plays a major role for the proper interpretation of the sea level evolution based on data derived from the coastal areas of the north-western Black Sea and the Sea of Asov. Subsidence in major river areas is a wide-spread phenomenon around the world (e.g., Törnqvist et al. 2006, Vött 2007) and therefore can also assumed for the Kuban river valley.

\section{Conclusion}

We can summarize our arguments as follows:

(1) Most of the studies which present major wiggles for the Black Sea level curve, underestimate or do not even take into account at all the factor of local tectonics. It is one of our research results that this factor is a prominent one and varies both temporally and spatially.

(2) That the bottom of the excavated well in Phanagoria reaches down to 7-8 $\mathrm{m}$ below the present sea-level may also be the effect of strong local subsidence.

(3) Sediment compaction should be considered as well as the effect of compaction due to earthquakes.

(4) We have calculated that the hydrodynamic effect of communicating water bodies - here Black and Azov Sea having been connected with the Mediterranean at least since $7.5 \mathrm{kyr}{ }^{14} \mathrm{C}$ BP - would equalize major differences in water levels within a couple of years; it is impossible that a dissymmetry could persist for centuries. Since none of the Mediterranean sea level curves shows the Phanagorian regression/transgression wiggle, it is doubtful that it ever existed. We think it is a misinterpretation of the data. Bearing in mind the tectonic setting 
(fig. 3), the trend of our sea level curves (fig. 6) fits well with similar curves for the Aegean Sea, showing a permanent post-glacial rise without being interrupted by major regressions/transgression wiggles.

(5) None of our corings shows a major erosional disconformity or a buried palaeosol. Both features should have evolved during a major drop in sea level for a couple of metres and a later rise for the same amount, at all of the sites that had been subaerially exposed.

(6) There is a good correlation between different tectonic units of Taman Peninsula and the four different groups of relative sea level curves (fig. 6). Burgaz Spit (S2) and Western Anapa Spit (S4) are located in two characteristic uplifting areas. The Gulf of Taman (S7, S8 and S9), Choushka Spit (S3) and the eastern part of Anapa Spit (S5 and S6) are located in a generally subsiding zone. Tectonic measurements (Nikonov 1994; Nikonov et al. 1997 ) confirm the subsidence in the central zone of the Taman peninsula. The present day subsidence at Temryuk and the Kuban delta is estimated between 3.5 and $4 \mathrm{~mm} / y e a r$, the tectonic part of it being about 2-3 mm/yr. For the Black Sea side, south of the peninsula, the average subsidence during the Upper Pleistocene is estimated at $2.5 \mathrm{~mm} / \mathrm{yr}$. These data confirm that the subsidence rates vary from one point to the other in the peninsula.

(7) During the time of the so-called Phanagorian regression we have three age estimates from our corings which show a sea level at $0.60-2.70 \mathrm{~m}$ b.s.l. during the first millennium BC. Taking into account a moderate average subsidence rate of $0.10 \mathrm{~m} / \mathrm{ka}$ one has to subtract 0.25 $\mathrm{m}$. Therefore, without the later subsidence, sea level was between 0.35 and $2.35 \mathrm{~m}$ b.s.l.

(8) Finally, the above listed arguments hold not only true for the so-called Phanagorian regression, but also for the many other major wiggles of the sea level curves for the Black Sea shown in fig. 1. None of these regression/transgression cycles has been found in the Mediterranean (cf. fig. 7), and one of them has ever been found in the sea level fluctuation models, e.g. Lambeck et al. (2005, 2007), Sivan et al. (2001).

\section{References}

Abramov, A.P., 1999. Underwater archaeology and palaeogeographical reconstruction of classic Patrasys. In: Patrasys: results of research. V.1., Moscow; IA RAN: 63 (in Russian).

Aksu, A.E., Hiscott, R.N., Yaşar, D., Mudie, P.J., 1999. Deglacial and post-glacial water levels and water exchange across the Black Sea - Marmara Sea - Aegean Sea shelves, eastern Mediterranean region. In: Saito, Y., Ikehara, K., Katayama, H. (eds.), Land - Sea Link in Asia, Proceedings of an International Workshop on Sediment Transport and Storage in Coastal Sea-Ocean System, Tsukuba, 463-468.

Aksu, A.E., Hiscott, R.N., Mudie, P.J., Rochon, A., Kaminski, M.A., Abrajano, T., Yaşar, D., 2002a. Persistent Holocene outflow from the Black Sea to the Eastern Mediterranean contradicts Noah's Flood hypotheses. GSA Today 12 (5), 4-10.

Aksu, A.E., Hiscott, R.N., Kaminski, M.A., Mudie, P.J., Gillespie, H., Abrajano, T., Yaşar, D., 2002b. Last glacial-Holocene paleoceanography of the Black Sea and Marmara Sea: stabile isotopic, foraminiferal and coccolith evidence. Marine Geology 190, 119-149.

Artyukhin, I.V., Grudinova, L.Y., Obukhovskaya, I.N., 1989. Ravnovesnye beregovye formy kak osnova dlia paleogeograficheskikh rekonstruktsii [Similarity coastal forms as a basis for paleogeographic reconstructions). Izvestiia AN SSSR, seriia geograficheskaiia 3, 91-96. (In Russian) 
Balabanov, I.P., 2007. Holocene sea-level changes of the Black Sea. In: Yanko-Hombach, V., Gilbert, A.S., Panin, N., Dolukhanov, P.M. (eds.), The Black Sea Flood Question. Springer, Dordrecht, 711-730.

Balabanov, I.P., 2009. Paleogeographical background to modern natural condition of the Caucasus littoral Holocene terraces and their long-term development forcast. Dalnauka, Moscow. 352 pp.

Balabanov, I.P., Gey, N.A., 1981. Istoriia razvitiia pitsundskoi laguny v srednem i verkhnem golotsene [History of the evolution of Pitsunda lagoon in the Middle and Upper Holocene]. In: Seliverstov, Y.P. (ed.), Palinologiia pleistotsena i golotsena [Pleistocene and Holocene Palynology], 78-87. Izdatel'stvo Leningradskogo Universiteta, Leningrad (in Russian).

Balabanov, I.P., Kvirkveliya, B.D., Ostrovsky, A.B., 1981. Noveishaia istoriia formirovaniia inzhenernogeologicheskikh uslovii i dolgosrochnyi prognoz razvitiia beregovoi zony poluostrova Pitsunda [Recent history of the development of engineering - geological conditions and long-time forecast for the coastal zone of the Pitsunda Peninsula]. Metsniereba, Tbilisi (in Russian).

Balabanov, I.P., Gaprindashvili, M.V., 1987. K voprosu o mestopolozhenii drevnegrecheskikh gorodov Pitiunt i Dioskuriia [On the question of the location of the ancient Greek cities Pitiunt and Dioskuriya]. Izvestiia AN GSSR, seriia istorii, arkheologii, etnografii i istorii iskusstva 2, 151-159 (in Russian).

Balabanov, I.P., Izmailov, Y.A., 1988. Izmenenie urovennogo i gidrokhimicheskogo rezhima Chernogo i Azovskogo morei za poslednie 20 tysiach let [Sea-level and hydrochemical changes of the Black Sea and Azov Sea during the last 20000 years]. Vodnye resursy 6, 54-62 (in Russian).

Balandin, Y.G., Trashchuk, N.N., 1982. Kolebaniia urovnia moria v golotsene i ikh otrazhenie v stroenii litifitsirovannykh rakushechnykh otlozhenii Arabatskoi kosy Azovskogo moria [Sea-level changes in the Holocene and their reflection in the structure of lithified coquina sediments of the Arabatkaia spit on the Sea of Azov]. In: Kaplin, P.A. (ed.), Izmeneniia urovnia moria [Sea Level Fluctuations], 227-237. Izdatel'stvo Moskovskogo Universiteta, Moscow (in Russian).

Ballard, R.D., Coleman, D.F., Rosenberg, G.D., 2000. Further evidence of abrupt Holocene drowning of the Black Sea shelf. Marine Geology 170, 253-261.

Bhattacharya, J.P., Walker, R.G., 1992. Deltas. In: Walker, R.G., James, N.P. (eds.), Facies Models: Response to sea-level change. Geological Association of Canada, 157-177, St. Johns.

Blavatsky, V.D., 1985. The underwater archaeological research on the northern shoreline of the Black Sea. In: Classic archaeology and history, 167-173. (In Russian). Science, Moscow.

Blagovolin, N.S., 1962. Geomorphology of the Kerch-Taman region. (In Russian) RAS, Moscow.

Blagovolin, N.S., Pobedonostsev, S.V., 1973. Recent vertical movements of the shores of Black and Azov Seas. Geomorphology 3, 46-55. (In Russian).

Bolikhovskaya, N., Kaitamba, M., Porotov, A., Fouache, E., 2004. The environmental changes of northeast Black Sea's coastal region during the Middle and Late Holocene (Chapter 17). In: Scott, E.M. (ed.), Impact of the Environment on Human Migration in Eurasia. Kluwer Academic Publishers (Netherlands), 209-223

Brückner, H., Müllenhoff, M., Gehrels, R., Herda, A., Knipping, M., Vött, A., 2006. From archipelago to floodplain - geographical and ecological changes in Miletus and its environs during the past six millennia (Western Anatolia, Turkey). Zeitschrift f. Geomorphologie N.F., Suppl.-Vol. 142, 63-83.

Brückner, H., Kelterbaum, D., Marunchak, O., Porotov, A., Vött, A., 2010. The Holocene sea level story since $7500 \mathrm{BP}-$ lessons from the Eastern Mediterranean, the Black and the Azov Seas. Quaternary International 225 (2), 16-179.

Chepalyga, A., 1984. Inlands sea basins. In : Velichko, A.A., Wright, H.E., Barnosky, C.W. (eds.), Late Quaternary Environments of the Soviet Union, University of Minnesota Press. Minneapolis, pp.237-240. 
Chepalyga, A.L., 2002. The Black Sea. In: Velichko, A.A. (ed.), Dynamics of Terrestrial Landscape Components and Inner Marine Basins of Northern Eurasia during the Last 130,000 years. GEOS, Moscow, 170182 (in Russian).

Chepalyga, A.L., 2007. The late glacial great flood in the Ponto-Caspian basin. In: Yanko-Hombach, V., Gilbert, A.S., Panin, N., Dolukhanov, P.M, (eds.), The Black Sea Flood Question. Springer, Dordrecht, 119-148.

Coleman, J.M., Roberts, H.H., Stone, G.W., 1998. Mississippi River delta: an overview. Journal of coastal research $14(3), 698-716$.

Dzhanelidze, C.P., 1980. Paleogeografiia Gruzii v golotsene [Paleogeography of Georgia in the Holocene]. Metsniereba, Tbilisi. (In Russian)

Dzhanelidze, Z.C., 2007. Amplituda Fanagori'skoi regressii Chernogo morya [The amplitude of Fanagorian regression of Black sea]. In: Problems of the coastal zone management and sustainable development. Abstracts XXII Intrnational . Coastal conference. Gelendjik (Russia), May 16-20, 2007. pp.327-328.

Fedorov, P.V., 1963. Stratigrafija Krimsko-Kavkazskogo pobrezija I nekotorie voprosi geologicheskoi istorii Chernogo morja [Stratigraphy of quaternary deposits of Crimean-Caucasian coastline and several questions of geological history of the Black Sea]. Trudi GIN AN SSSR Moscow Science, tom. 88 . [Transactions Geol. Inst. RAS. Moscow, Science 88.]

Fedorov, P.V., 1977. Pozdnechetvertichnaia istoriia Chernogo moria i razvitie iuzhnykh morei Evropy [Late Quaternary history of the Black Sea and evolution of the southern seas of Europe]. In: Kaplin, P.A., Shcherbakov, F.A. (eds.), Paleogeografiia i otlozheniia pleistotsena iuzhnykh morei SSSR [Pleistocene Paleogeography and Sediments of the Southern Seas of the USSR], 25-32. Nauka, Moscow (in Russian).

Fedorov, P.V., 1978. Pleistocene Ponto-Kaspiya. Moskva, Nauka. [Pleistocene of the Ponto-Caspain region]. Moscow, Science. 166p. (In Russian)

Fontugne, M., Guichard, F., Strechie, C., Lericolais, G., 2009. Reservoir age of the Black Sea waters during anoxic periods. Radiocarbon 51 (3). 969-976.

Fouache, E., Müller, C., Gorlov, Y., Gaibov, V., Porotov, A., 2000a. Geoarchaeological study of the Taman peninsula and the Kuban delta (Black Sea, Azov Sea, Russia). In: Vermeulen, F., Papperde, M. (eds.), Geoarchaeology of the Landscapes of Classical Antiquity. Stichting Bulletin Antike Beschaving 5 (Supplement), 97-104. International colloquium Ghent, 23-24 October 1998. Coll. Babesch. Leiden.

Fouache, E., Dufaure, J.J., Faivre, S., 2000b. New evolution on the evolution of the Croatian shore between Poreç and Zadar over the past 2000 years. Zeitschrift für Geomorphologie, Suppl. Bd. 122, 3-46.

Fouache, E., Porotov, A., Muller, C., Gorlov, Y., 2004. The role of neo-tectonics in the variaton of the relative mean sea level throughout the last 6000 years on the Taman Peninsula (Black Sea, Azov Sea, Russia). In: Colloque Rapid Transgressions into Semi-enclosed Basins. PICG 464. Polish Geological Institute, Special Papers 11. Polish Geological Institute, Gdansk, 47-58. 8-10 Mai 2003.

Flemming, N.C., 1979. Archaeological indicators of sea-level. In: Les indicateurs de niveaux marins. Océanis, Fascicules Hors-Séries 5, 184-191.

Giosan, L., Donnelly, J.P., Constantinescu, S., Filip, F., Ovejanu, I., Vespremeanu-Stroe, A., Vespremeanu, E., Duller, G.A.T., 2006. Young Danube delta documents stable Black Sea level since the middle Holocene: morphodynamic, paleogeographic, and archaeological implications. Geology 34 (9), 757-760.

Glebov, A.Y., Shel'ting, S.K., 2007. Sea-level changes and coastline migrations in the Russian sector of the Black Sea: application to the Noah's flood hypothesis. In: Yanko-Hombach, V., Gilbert, A.S., Panin, N., Dolukhanov, P.M. (eds.), The Black Sea Flood Question. Springer, Dordrecht, 731-774. 
Govedarica, B., 2003. On the oscillations of the Black Sea level in the Holocene period from an archaeological viewpoint. In: Wagner, G.A., Pernicka, E., Uerpmann, H.P. (eds.), Troia and the Troad. Scientific Approaches. Natural Science in Archaeology. Springer, Berlin, Heidelberg, New York, 95-104.

Gozhik, P.F., Novosel'sky, F.A., 1989. Geologicheskie usloviia stroitel'stva Dneprovsko-Bugskogo gidrouzla [Geological Conditions of Building of Dnieper-Bugsky Gauge Station]. Naukova Dumka, Kiev (in Russian).

Hiscott, R.N., Aksu, A.E., Yaşar, D., Kaminski, M.A., Mudie, P.J., Kostylev, V.E., MacDonald, J.C., Isler, F.I., Lord, A.R., 2002. Deltas south of the Bosphorus Strait record persistent Black Sea outflow to the Marmara Sea since $10 \mathrm{ka}$. Marine Geology 190, 95-118.

Hughen, K.A., Baillie, M.G.L., Bard, E., Bayliss, A., Beck, J.W., Bertrand, C., Blackwell, P.G., Buck, C.E., Burr, G., Cutler, K.B., Damon, P.E., Edwards, R.L., Fairbanks, R.G., Friedrich, M., Guilderson, T.P., Kromer, B., McCormac, F.G., Manning, S., Bronk Ramsey, C., Reimer, P.J., Reimer, R.W., Remmele, S., Southon, J.R., Stuiver, M., Talamo, S., Taylor, F.W., Plicht, J. van der, Weyhenmeyer, C.E., 2004. Marine04. Marine radiocarbon age calibration, 0-26 cal kyr BP. Radiocarbon 46 (3), 1059-1086.

Inozemtsev, Y.I., Luciv, Y.K., Sobotovich, E.V., Kovalyukh, N.N., Petrenko, L.V., 1984. Geochronologiia i fatsialnie kompleksi golotsena Chernomorskoi oblasti [Geochronology and Holocene facies complexes of the Pontic area]. In: Shnyukov, E.F., Aksenov, A.A., Glazunova, K.N., Melnik, V.I., Mitropol'sky, A.Y. (eds.), Izuchenie geologicheskoi istorii i protsessov sovremennogo osadkoobrazovaniia Chernogo i Baltiiskogo morei: Trudy mezhdunarodnogo simpoziuma [Study of the geological history and processes of recent sedimentation in the Black and Baltic Seas], Part 1, 103-113. Naukova Dumka, Kiev (in Russian).

Izmailov, Y., 2007. Late Holocene coastlines of the Sea of Azov in the Kuban River delta. In: Chepalyga, A., Izmailov, Y., Zin'ko, V. (Eds.), Field Trip Guide. IGCP 521-481 Joint Meeting and Field Trip, Fig. 18 a, p. 36.

Izmailov, Y.A., Arslanov, K.A., Tertychnaya, T.V., Chernov, S.B., 1989. Rekonstruktsiia i datirovanie golocenovykh beregovykh linii moria v del'te Kubani Vostochnoe Azovo-Chernomor'e [Reconstruction and dating of Holocene shorelines in the delta of the Kuban River, eastern coast of the Sea of Azov and Black Sea]. Vestnik LGU (ser. 7) 321, 61-69 (in Russian).

Jones, G.X., Gagnon, A.R., 1994. Radiocarbon chronology of Black Sea sediments - Deep Sea research part I. Oceanic research papers 41 (3), 531-557.

Kaminski, M.A., Aksu, A.E., Box, M., Hiscott, R.N., Filipescu, S., Al-Salameen, M., 2002. Late Glacial to Holocene benthic foraminifera in the Marmara Sea: implications for Black Sea - Mediterranean Sea connections following the last deglaciation. Marine Geology 190, 165-202.

Kaplin, P., Porotov, A., Yanina, T., Gorlov, Y., Fouache, E., 2001. O vozraste I uslovijach formirovaaanija Bugazskoi peresipi. [The Age of Bugaz spit and peculiarity of its formation] Vestnik Moskovskogo universiteta, Geografia [Review of Moscow state University, Geography. 2,], 51-57.

Kelterbaum, D., Brückner, H., Porotov, A., Schlotzhauer, U., Zhuravlev, D. Geoarchaeology of Taman Peninsula (SW Russia) - the example of the ancient Greek settlement of Golubitskaya 2. Die Erde (in review).

Kondrashov, A., 1995. Underwater investigations at Cape Panagia on the Taman Peninsula, Straits of Kerch. The International Journal of Nautical Archaeology 24 (2), 109-119.

Konikov, G.K., 2007. Sea-level fluctuations and coastline migration in the northwestern Black Sea area over the last $18 \mathrm{ky}$ based on high-resolution lithological-genetic analysis of sediment architecture. In: Yanko-Hombach, V., Gilbert, A.S., Panin, N., Dolukhanov, P.M. (eds.), The Black Sea Flood Question. Springer, Dordrecht, 405436.

Kraft, J.C., Brückner, H., Kayan, I., Engelmann, H. 2007. The geographies of ancient Ephesus and the Artemision in Anatolia. Geoarchaeology 22 (1), 121-149.

Krustev, A., Grigoriev, A., Fedorov, P., 1990. Biostratigraphy of the Pleistocene of the Bulgarian Black Seas Shelf and the problem for the transgressive-regressive cycles of the Black Sea. In: Geological Evolution of the Western part of the Black Sea depression during the Neogene-Quaternary, 340-348. Sofia (in Russian). 
Kwiecien, O., Arz, H.W., Lamy, F., Plessen, B., Bahr, A., Haug, G.H., 2009. North Atlantic control on precipitation pattern in the eastern Mediterranean/Black Sea region during the last glacial. Quaternary Research $71,375-384$.

Kwiecien, O., Arz, H.W., Lamy, F., Wulf, S., Bahr, A., Rohl, U., Haug, G.H., 2008. Estimated reservoir ages of the Black Sea since the last glacial. Radiocarbon 50, 99-118.

Lambeck, K., Purcell, A., 2005. Sea-level change in the Mediterranean Sea since the LGM: model predictions for tectonically stable areas. Quaternary Science Reviews 24, 1969-1988.

Lambeck, K., Sivan, D., Purcell, A., 2007. Timing of the last Black Sea - Mediterranean connection from isostatic models and regional sea-level data. In: Yanko-Hombach, V., Gilbert, A.S., Panin, N., Dolukhanov, P.M. (eds.): The Black Sea Flood Question: Changes in Coastline, Climate, and Human Settlement, 797-808. Springer, New-York.

Lericolais, G., Popescu, I., Guichard, F., Popescu, S.-M., Manolakakis, L., 2007. Waterlevel fluctuations in the Black Sea since the Last Glacial Maximum. In: Yanko-Hombach, V., Gilbert, A.S., Panin, N., Dolukhanov, P.M. (eds.), The Black Sea Flood Question. Springer, Dordrecht, 437-452.

Lericolais, G., Bulois, C., Gillet, H., Guichard, F., 2009. High frequency sea level fluctuations recorded in the Black Sea since the LGM. Global and Planetary Change 66, 65-75.

Lericolais, G., Guichard, F., Morigi, C., Minereau, A., Popescu, I., Radan, S., 2010. A post Younger Dryas Black Sea regression identified from sequence stratigraphy correlated to core analysis and dating. Quaternary International 225, 199-209.

Marret, F., Mudie, P., Aksu, A., Hiscott, R.N., 2009. A Holocene dinocyst record of a two-step transformation of the Neoeuxinian brackish water lake into the Black Sea. Quaternary International 197, 72-86.

Mayewski, P., Rohling, E.E., Stager, J.C., Karlén, W., Maasch, K.A., Meeker, L.D., Meyerson, E.A., Gasse, F., van Kreveld, S., Holmgren, K., Lee-Thorp, J., Rosqvist, G., Staubwasser, M., Schneider, R.R., Steig, E.J., (2004). Holocene climate variability. Quaternary research 62 (3), 243-255.

Meisner, A., Krylov, O., Nem, M., 2009. Development and structural architecture of the Eastern Black Sea. The Leading Edge 28, 1046-1055.

Molodykh, I.I., V.P. Usenko, N.N. Palatnaya, N.N. Kochubey, M.F. Polozhevets, P.F. Gozhik, N.A. Garkusha, V.D. Ponomarenko, V.S. Martynov, V.A. Boltivets, F.A. Novosel'sky, P.S. Slipchenko, M.F. Rotar', V.M. Voskoboinikov, E.G. Konikov, P.N. Naumenko, E.T. Palienko, V.V. Stetsyuk, 1984. Geologiia shel'fa USSR. Limany [Geology of the USSR Shelf. Limans]. Naukova Dumka, Kiev (in Russian).

Morhange, C., Laborel, J., Hesnard, A., 2001. Changes of relative sea level during the past 5000 years in the ancient harbor of Marseilles, Southern France. Palaeogeography, Palaeoclimatology, Palaeoecology 166, 319329.

Nevessky, E.N., 1967. Processe osadkonakopleniya v proibreznoi zone morya [The processes of sedimentation in the near shore zone. Moscow, Nauka, Moscow. 255 p.

Nikonov, A.A., 1994. Severe earthquakes in the Krasnodar reservoir region - New evaluations. Power Technology and Engineering (formerly Hydrotechnical Construction) 28 (5), 281-284.

Nikonov A., Enman S.V., Mishin A.V., 1997. Sovremennie verticalnie dvizeniya zemnoi kori na poberez'jah Chernogo I Azovskogo morey [The recent vertical Earth crust movements on the Azov and Black Sea shorelines] Proc. RAS 357 (6), 818-822. (in Russian).

Nikonov A. 1998. Zatoplennie oststki antichnogo vremeni po beregam Bospora Kimmeriyskogo [The flooded remnants of classic time on the coasts of Bosporus Cimmerian] Rossiysskaya archeologija

[Russian Archaeolology. №3. pp.57-66.] (in Russian) 
Ostrovsky, A.B., Izmailov, Y.A., Balabanov, I.P., Skiba, S.I., Skryabina, N.G., Arslanov, K.A., Gey, N.A., Suprunova, N.I., 1977. Novye dannye o paleogidrologicheskom rezhime Chernogo moria v verkhnem pleistotsene i golosene [New data on the paleogeographical regime of the Black Sea in the Late Pleistocene and Holocene]. In: Kaplin, P.A., Shcherbakov, F.A. (eds.), Paleogeografiia i otlozheniia pleistotsena iuzhnykh morei SSSR [Pleistocene paleogeography and sediments of the southern seas of the USSR], 131-140. Nauka, Moscow (in Russian).

Panin, N., Popescu, I., 2007. The northwestern Black Bea: climatic and sea level changes in the Upper Quaternary. In: Yanko-Hombach, V., Gilbert, A.S., Panin, N., Dolukhanov, P.M. (eds.): The Black Sea Flood Question: Changes in Coastline, Climate, and Human Settlement, pp. 387-404. Springer, New-York.

Paromov, J.M., 2006. The Taman Peninsula during the early antiquity $\left(6^{\text {th }}-5^{\text {th }}\right.$ century BC). DB 2006 , table 10. (in Russian).

Pitman, W.C., Ryan, W.B.F., 1998. Noah's flood. The new scientific discoveries about the event that changed history. Simon and Schuster, New York.

Pirazzoli, P., 1979. Les viviers à poissons romains en Méditerranée. In: Oceanis, Fasc. Hors Série 5, 184-191.

Pirazzoli, P., 1991. World Atlas of Holocene Sea-Level Changes. Elsevier Oceanography Series, 58.

Porotov, A., 2007. Relative sea-level changes and submersion of archaeological sites along the northern shoreline of the Black Sea. Mediterranée 108 (1), 29-36.

Reimer, P.J., Baillie, M.G.L., Bard, E., Bayliss, A., Beck, J.W., Bertrand, C., Blackwell, P.G., Buck, C.E., Burr, G., Cutler, K.B., Damon, P.E., Edwards, R.L., Fairbanks, R.G., Friedrich,M.,Guilderson, R.P.,Hughen, K.A., Kromer,B.,McCormac, F.G.,Manning, S., Ramsey, C.B., Reimer, R.W., Remmele, S., Southon, J.R., Stuiver, M., Talamo, S., Taylor, F.W., Plicht, J. van der, Weyhenmeyer, C.E., 2004. INTCAL04 terrestrial radiocarbon age calibration, 0-26 kyr BP. Radiocarbon 46 (3), 1029-1058.

Ryan, W.B.F., 2007. Status of the Black Sea flood hypothesis. In: Yanko-Hombach, V., Gilbert, A.S., Panin, N., Dolukhanov, P.M. (Eds.), The Black Sea Flood Question. Springer, Dordrecht, pp. 63-88.

Ryan, W.B.F., Pitman, W.C., Major, C.O., Shimkus, K., Moskalenko, V., Jones, G.A., Dimitrov, P., Görür, N., Sakınç, M., Seyir, H.I., Yüce, H., 1997. An abrupt drowning of the Black Sea shelf. Marine Geology 138, 119126.

Saintot, A., Angelier, J., 2000. Plio-Quaternary paleostress regimes and relation to structural development in the Kertch-Taman Peninsulas (Ukraine and Russia). Journal of Structural Geology 22, 1049-1064.

Shilik, K., 1975. Paleogeografii ol'vii. In: Krzhitskii, S.D. (ed.), Ol'viya. Kiev, 51-91 (in Russian).

Shilik, K., 1975. Ismeneniya urovnya Chermogo morya $\mathrm{v}$ posdnem golotsene po materiallam geomorfologicheskih i archaeologicheskih isledovanii v severozapadnoi chasti basseina. Avtoreferet dissertatsi na soiskanii uchenoi stepeni kandidata geograficheskih nauk. Leningrad (in Russian).

Shilik, K., 1997. Oscillations of the Black Sea and ancient landscapes. In: Chapman, J., Dolukhanov, P. (eds.), Landscapes in flux: Central and Eastern Europe in Antiquity, 115-129.

Shnyukov, E.F., Alenkini, V.M., Put, A.L., 1981. The geology of shelf of Ukraine: the Kerch Strait. Navkova Dumka : 180. Kiev (In Russian).

Siddall, M., Pratt, L.J., Helfrich, K.R., Giosan, L., 2004. Testing the physical oceanographic implications of the suggested sudden Black Sea infill 8400 years ago. Paleoceanography 19, 1-11.

Sivan, D., Wdowinski, S., Lambeck, K., Galili, E., Raban, A., 2001. Holocene sea-level changes along the Mediterranean coast of Israel, based on archaeological observations and numerical model. Palaeogeography, Palaeoclimatology, Palaeoecology 167, 101-117. 
Sornoza, L., Barnolas, A., Arasa, A., Maestro, A., Rees, J.G., Hernandez-Molina, F.J., 1998. Architectural stacking patterns of the Ebro delta controlled by Holocene high-frequency eustatic fluctuations, delta-lobe switching and subsidence processes. Sedimentary Geology 117 (1-2), 11-32.

Soulet, G., Delaygue, G., Vallet-Coulomb, C., Böttcher, M.E., Sonzogni, C., Lericolais, G., Bard, E., 2010. Glacial hydrologic conditions in the Black Sea reconstructed using geochemical pore water profiles. Earth and Planetary Science Letters 296, 57-66.

Sperling, M., Schmiedl, G., Hemleben, C., Emeis, K. C., Erlenkeuser, H., Grootes, P.M., 2003. Black Sea impact on the formation of eastern Mediterranean sapropel S1? Evidence from the Marmara Sea. Palaeogeography, Palaeoclimatology, Palaeoecology 190, 9-21.

Streif, H., 1990. Quaternary sea level changes in the North Sea, an analysis of amplitudes and velocities. In: Brosche, P., Sündermann, P.J. (eds.), Earth's rotation from eons to days, 201-214, Berlin.

Streif, H., 2004. Sedimentary record of Pleistocene and Holocene inundations along the North Sea coast of Lower Saxony, Germany. Quaternary International 112 (1), 3-28.

Stuiver, M., Braziunas, T.F., 1993. Modeling atmospheric 14C influences and radiocarbon ages of marine samples back to 10000 BC. Radiocarbon, 35: 137-139.

Styan, W.B., Bustin, R.M., 1983. Sedimentology of Fraser river delta peat deposits: a modern analogue for some deltaic coals. International Journal of Coal Geology 3, 101-143.

Sudarev, N.I., Chevelov, O.D., 2010. Sustainable conservation of the western necropolis of Hermonassa in 2009. In: Masslennikov, A.A., Gavriluk, N.A., Savoikin, A.A. (eds.), Symbola 1, 220-223 (in Russian).

Thom, N., 2010. A hydrological model of the Black and Caspian Seas in the late Pleistocene and early-middle Holocene. Quaternary Science Reviews 29, 2989-2995.

Törnqvist, T.E., Bick, S.J., van der Borg, K., de Jong, A.F.M., 2006. How stable is the Mississippi delta? Geology 34, 697-700.

Tolmazin, D., 1985. Changing coastal oceanography of the Black Sea. I Northwestern Shelf. Progress in Oceanography 15, 217-276.

Vött, A., Brückner, H., 2006. Versunkene Häfen im Mittelmeerraum. Antike Küstenstädte als Archive für die geoarchäologische Forschung. Geographische Rundschau 58 (4), 12-21. Braunschweig.

Vött, A., Schriever, A., Handl, M., Brückner, H., 2007. Holocene palaeogeographies of the central Acheloos River delta (NW Greece) in the vicinity of the ancient seaport Oiniadai. In: ${ }^{\text {th }}$ Int. Conf. Geomorph., Sept 7-11, 2005, Zaragoza. Working Group Geoarchaeology. Geodinamica Acta 20 (4), Special Issue, 241-256.

Vorosmarty, C.J., Fekete, B.M., Tucker, B.A., 1998. Global river discharge, 1807-1991, V[ersion] 1.1 (RivDIS). Data set. Available online [http://www.daac.ornl.gov/rivdis/STATIONS.HTM] from Oak Ridge National Laboratory Distributed Active Archive Center, Oak Ridge, Tennessee, U.S.A. doi:10.3334/ORNLDAAC/199.

Yanko-Hombach, V., 2007. Controversy over Noah's Flood in the Black Sea: geological and foraminiferal evidence from the shelf. In: Yanko-Hombach, V., Gilbert, A.S., Panin, N., Dolukhanov, P.M. (eds.), The Black Sea Flood Question. Springer, Dordrecht, 149-204.

Zhuravlev, D., Schlotzhauer, U., Kelterbaum, D., 2010. New facilities on Taman Peninsula of the $6^{\text {th }}$ century BC. In: Masslennikov, A.A., Gavriluk, N.A., Savoikin, A.A. (eds.), Symbola 1, 69-73 (in Russian). 
Legends of Figures and Tables :

Fig. 1: Sea level curves of the Black Sea as noted by various authors. It is obvious that most of the curves have major transgression/regression cycles ("wiggles") which do, however, vary significantly. The inserted map focuses on the so-called Phanagorian regression featured by all of the authors except for Nevessky (curve C). In the compiled curves the regression maximum varies from $-5 \mathrm{~m}$ to $-11 \mathrm{~m}$. Source: own compilation based on various sources.

Fig. 2: Overview of the Taman Peninsula with the settlements and coring sites mentioned in the text. The areas of import for this study are highlighted. Coring sites are indicated by a white dot. Source: own compilation based on Landsat 7 and SRTM data.

Fig. 3: Major tectonic features of the Eastern Black Sea region with location of mud volcanoes and magnetic anomalies. Isobaths are in meters. Modified from Meisner et al. (2009).

Fig. 4: Active cliffs and palaeo-cliffs of Taman Peninsula. Left photograph: Strong cliff erosion at the present shores of the Sea of Azov close to Peresip. The Golubitskaya sand barrier is separating the Akthanizovskaya Liman from the Sea of Azov. Right photograph: Palaeo-cliff structure bordering the Soleni Liman in the centre of the Taman Peninsula.

Fig. 5: Example of a typical coring in the centre of the Kuban delta plain. Coring DZHI 2 at Dschiginka) is shown with photographic documentation of the coring tubes [total coring depth:

$14 \mathrm{~m}$ below surface (b.s.); diameter of augerheads: $6 \mathrm{~cm}$ (for $0-6 \mathrm{~m}$ b.s.), $5 \mathrm{~cm}$ (for 6$14 \mathrm{~m}$ b.s.), geological profile and ${ }^{14} \mathrm{C}$ age estimates. As for the location of the coring site see fig. 2 .

Fig. 6: Compilation of different sea level curves from Taman Peninsula based on results from corings.

Left side: Brückner et al. (2010) for SEM = Semebratnee, the ancient city of Labrys, Kelterbaum et al. (in review) for GOL = Golobitskaya, supplemented by research in the Kuban delta (DZHI = Dschiginka). The envelope bands give possible variation widths concerning the altitude of the sea level at a given time.

Right side: Fouache et al. (2004). S2 = Burgaz Spit, S3 = Chouska Spit, S4, S5 and S6 = Anapa Spit.

Fig. 7: Sea level curves for different parts of the Eastern Mediterranean. Source: Vött \& Brückner (2006).

Table 1: Average annual discharge of the most important rivers that flow into the Black Sea basin with maximum, minimum and mean values. Sources: Vorosmarty et al. 1998; Global River Discharge Database (updated 02/13/2010): http://www.sage.wisc.edu/riverdata/index.php?qual=32

Table 2 : Radiocarbon Dates. All ages are calibrated with the calibration software Calib 5.0.2. For marine carbonates the reservoir age of 408 years (Hughen et al. 2004) is applied with delta R of $5 \pm 35$ years according to Jones \& Gagnon (1994) 
Table 3 : Radiocarbon Dates obtained on mollusc sample $\mathrm{M}(\mathrm{bs})=$ mollusc bulk sample $; \mathrm{M}=$ mollusc (single valve) at the Geological Institute of the Russian Academy of Sciences (GIN) and at the Geographical Faculty of Moscow State University (MGU). All ages are calibrated with the calibration software Calib 5.0.2. For marine carbonates the reservoir age of 408 years (Hughen et al. 2004) is applied with delta $R$ of $5 \pm 35$ years according to Jones \& Gagnon (1994) 


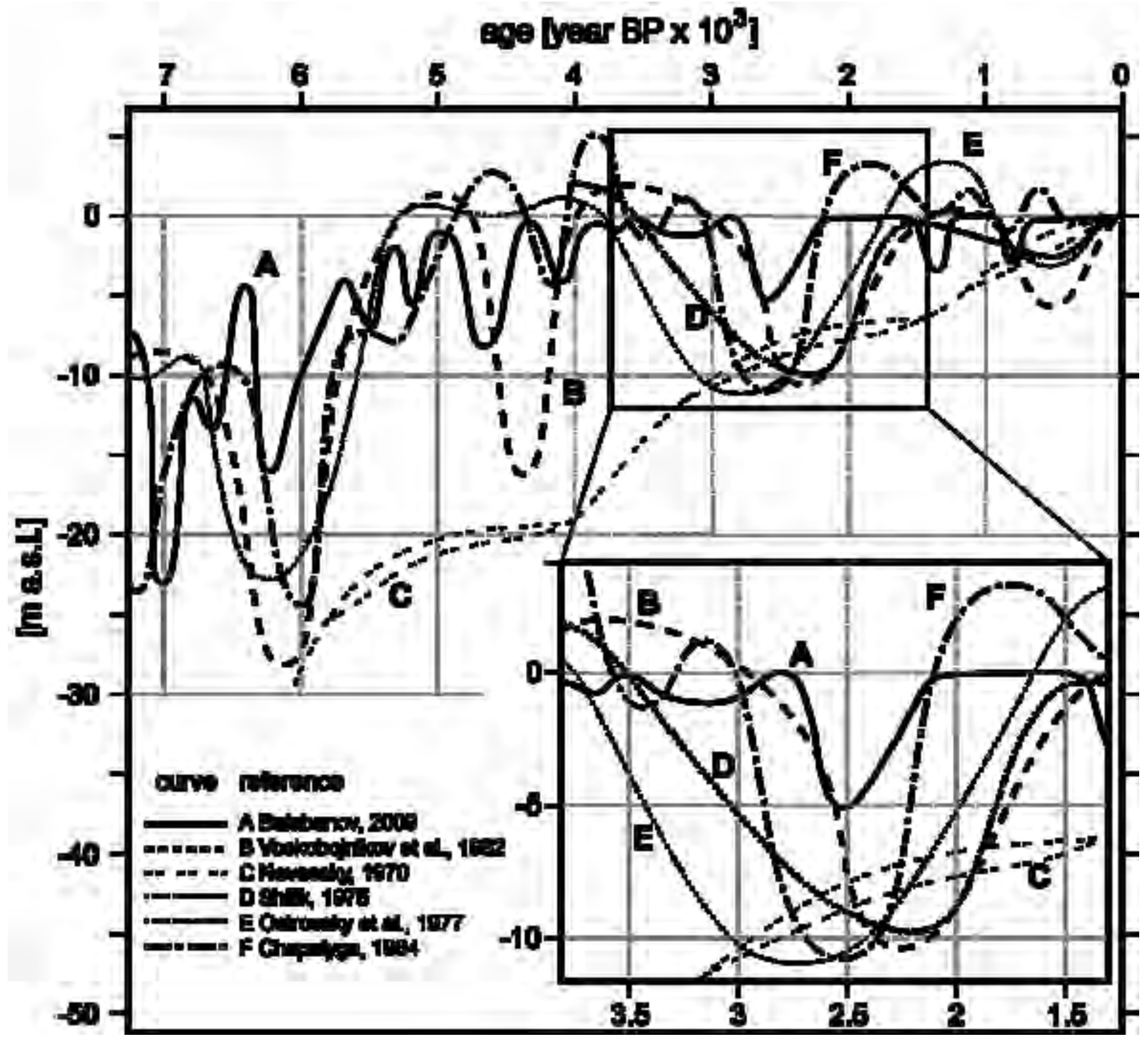


Click here to download high resolution image

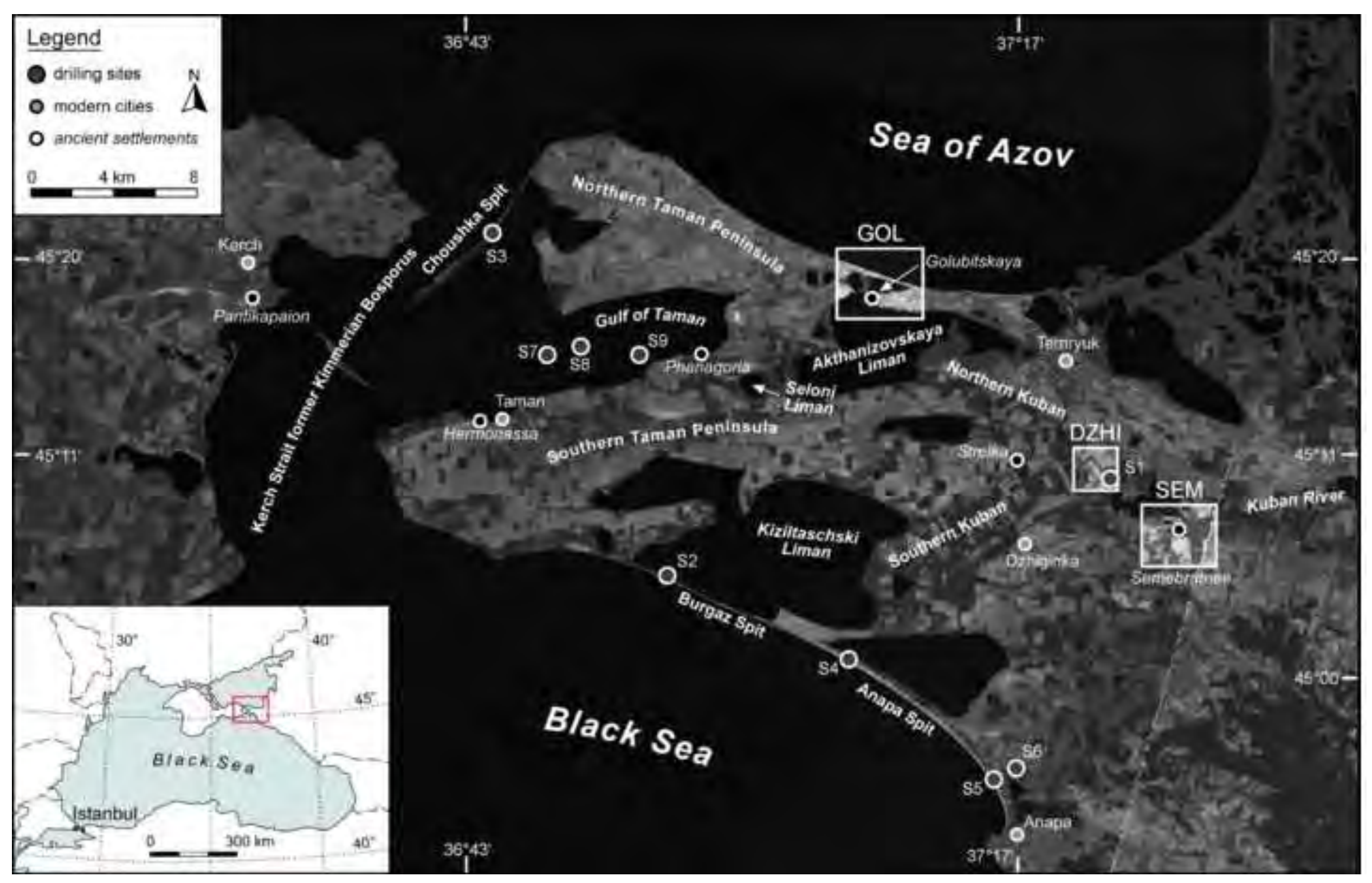


Click here to download high resolution image
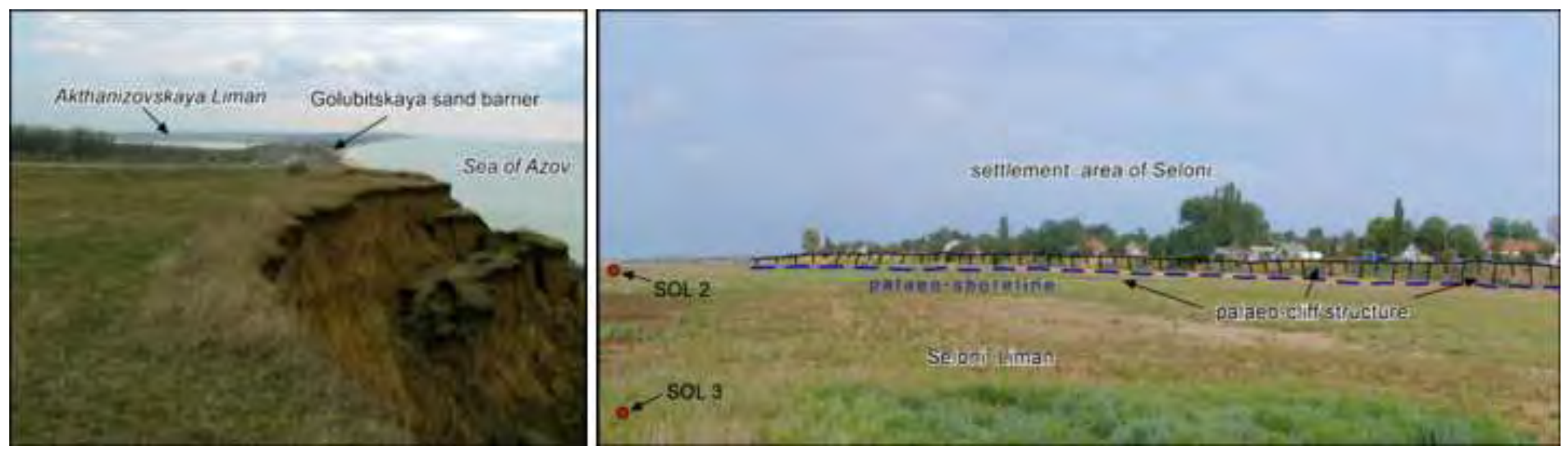


\section{Figure5}

Click here to download high resolution image
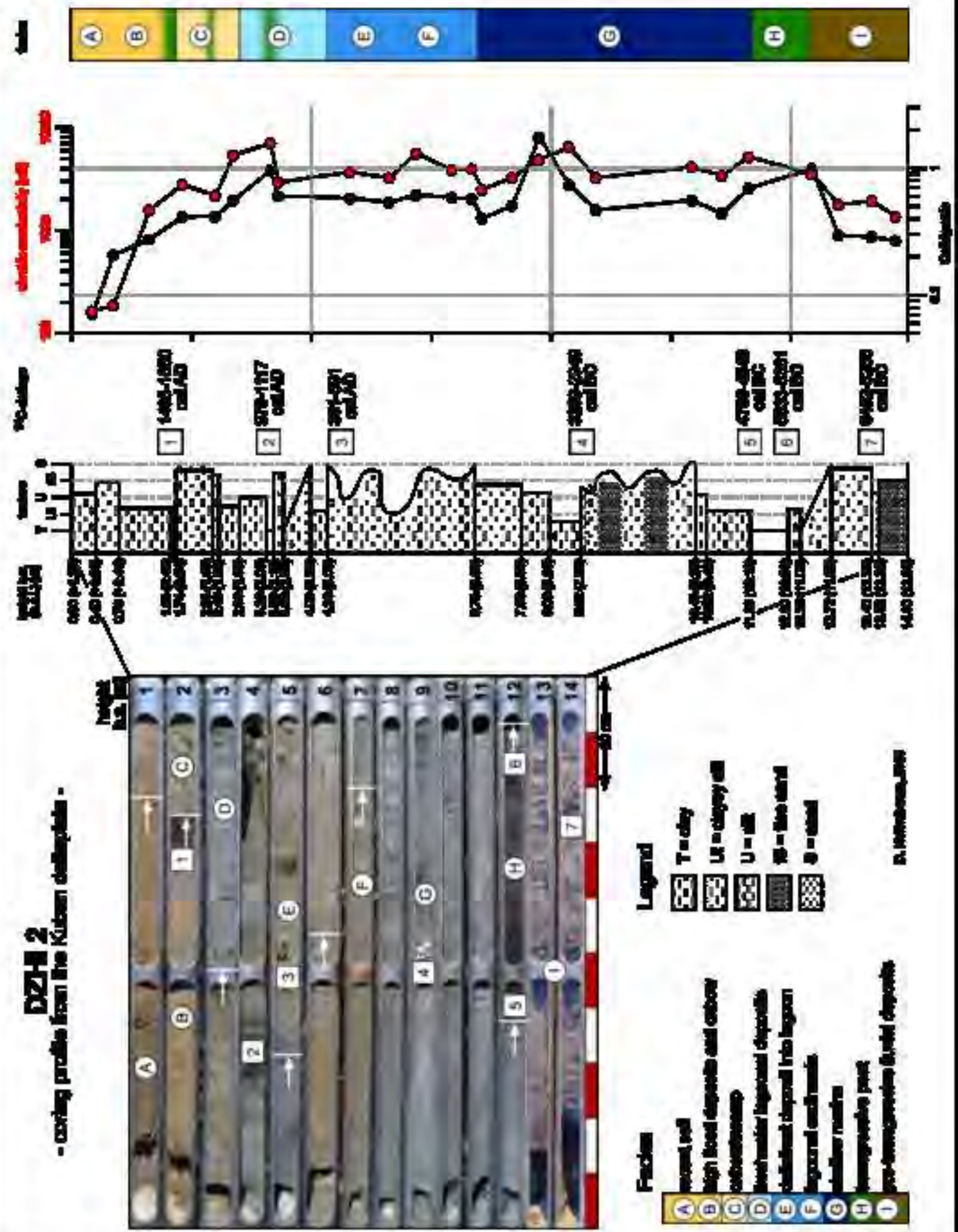

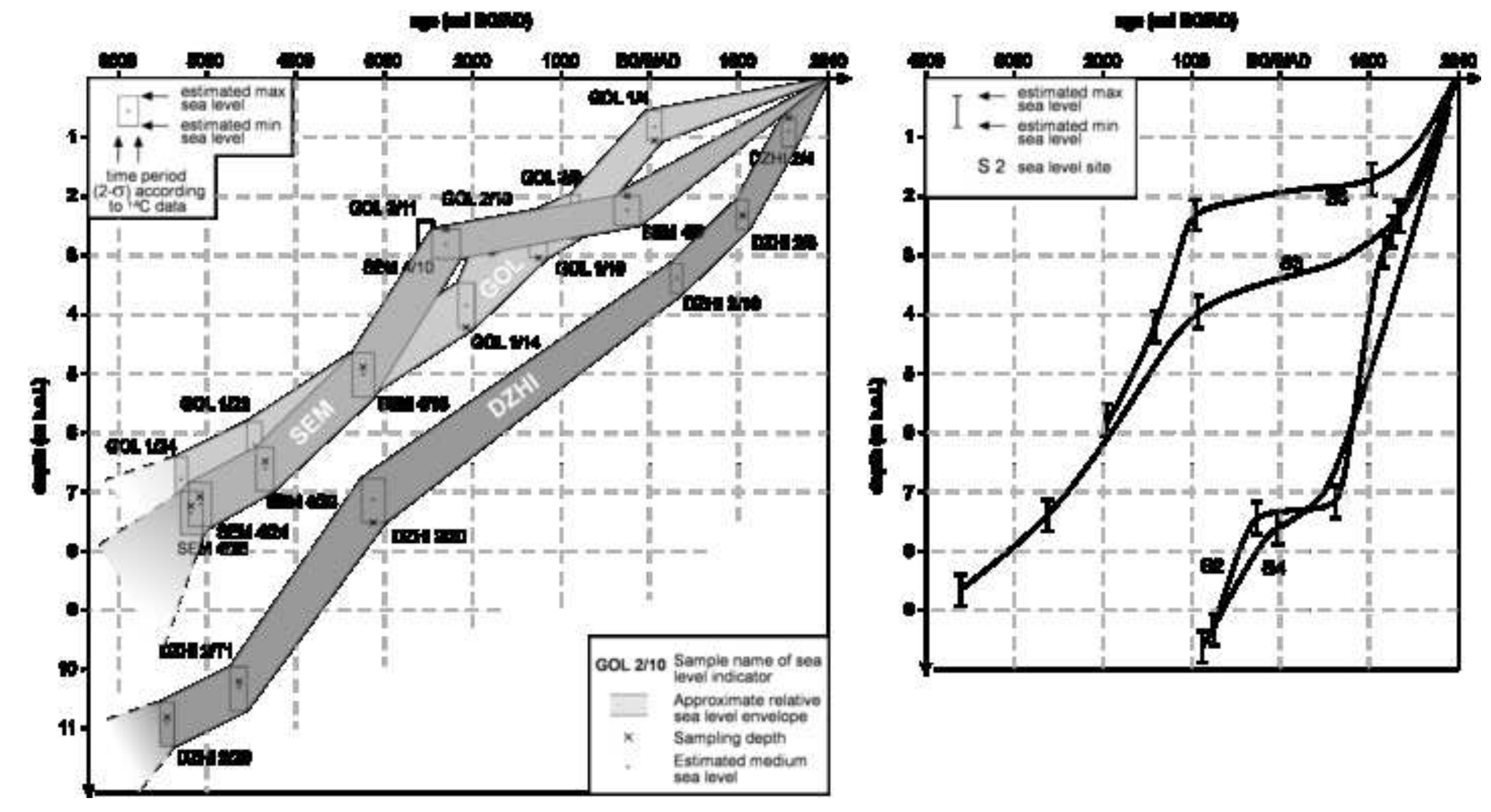


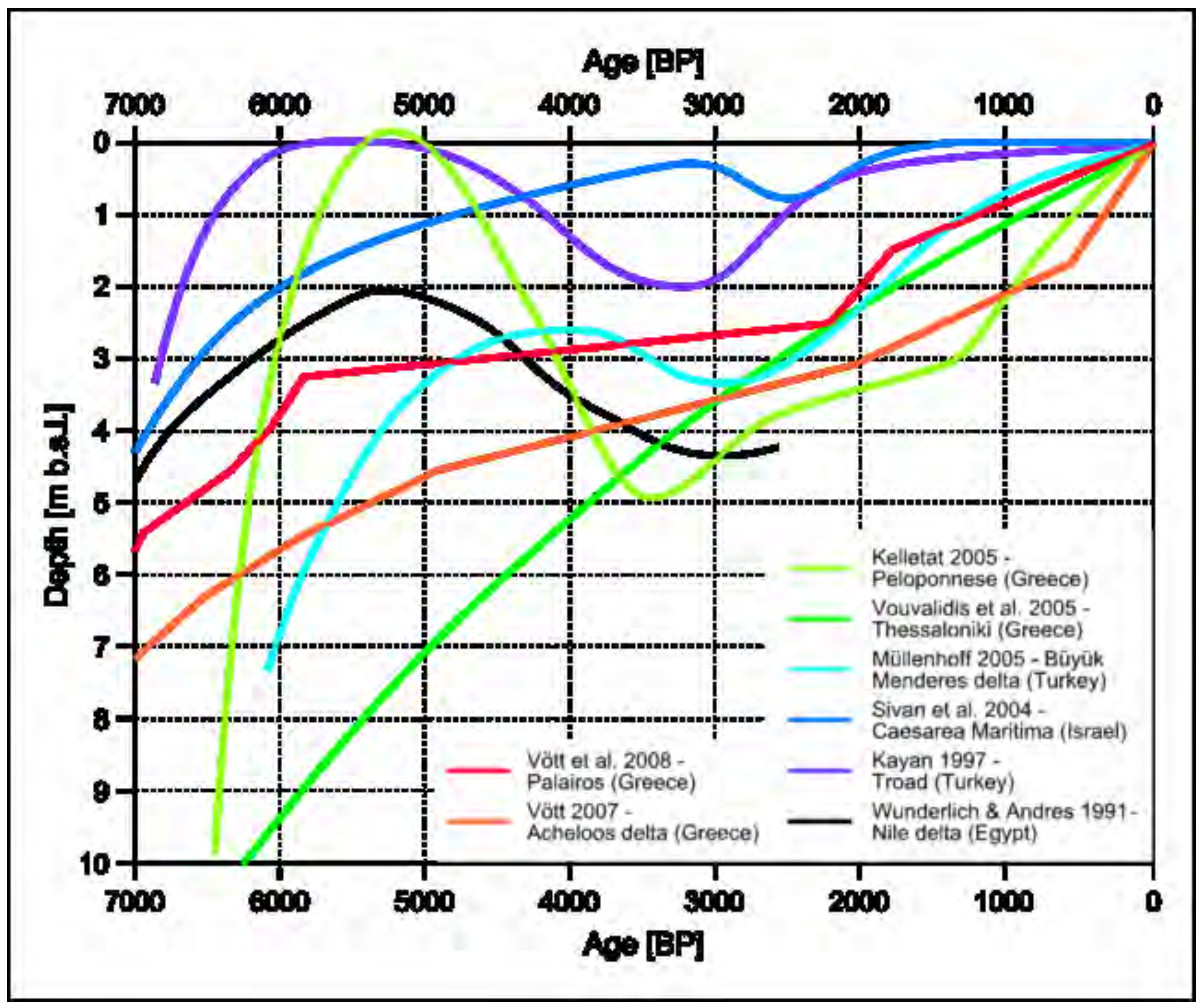




\begin{tabular}{|c|c|c|c|c|c|c|c|c|}
\hline \multirow[b]{2}{*}{ Sample ID } & \multirow[b]{2}{*}{ Lab. no. } & \multirow[b]{2}{*}{$\mathrm{d} 13 \mathrm{C}$} & \multirow[b]{2}{*}{ material } & & \multicolumn{2}{|c|}{ Calibrated ages } \\
\hline & & & & $\begin{array}{l}14 \mathrm{C} \\
(\mathrm{BP})\end{array}$ & $\begin{array}{l}\text { Age } \\
\pm \quad 1\end{array}$ & $1 \mathrm{~s}$ & $\begin{array}{c}\text { 1 Sigma max; min } \\
\text { (cal BP) }\end{array}$ & $\begin{array}{l}2 \text { Sigma max; min } \\
\text { (cal BC/AD) }\end{array}$ \\
\hline DZHI $2 / 4$ & UGAMS 03178 & $-27,13$ & PR & 301 & \pm 2 & 24 & $305 ; 428$ & $1495 \mathrm{AD} ; 1650 \mathrm{AD}$ \\
\hline DZHI $2 / 8$ & UGAMS 03179 & $-26,21$ & PR & 1015 & \pm 2 & 24 & $925 ; 955$ & $979 \mathrm{AD} ; 1117 \mathrm{AD}$ \\
\hline DZHI $2 / 10$ & UGAMS 04142 & 0,27 & $\mathrm{M}$ & 1937 & \pm 2 & 29 & $1410 ; 1529$ & $351 \mathrm{AD} ; 591 \mathrm{AD}$ \\
\hline DZHI $2 / 20$ & UGAMS 03180 & $-2,98$ & $\mathrm{M}$ & 4790 & \pm 2 & 25 & $4961 ; 5173$ & $3289 \mathrm{BC} ; 2949 \mathrm{BC}$ \\
\hline DZHI $2 / 29$ & UGAMS 03181 & $-28,30$ & PR & 7521 & \pm 3 & 30 & $8215 ; 8401$ & $6452 \mathrm{BC} ; 6266 \mathrm{BC}$ \\
\hline DZHI 2/T1 & UGAMS 03182 & $-28,30$ & PR & 5810 & & & $6563 ; 6666$ & $4769 \mathrm{BC} ; 4549 \mathrm{BC}$ \\
\hline DZHI 2/T8 & UGAMS 03183 & $-27,55$ & $\mathrm{PR}$ & 6511 & \pm 2 & 27 & $7419 ; 7459$ & $5533 \mathrm{BC} ; 5381 \mathrm{BC}$ \\
\hline GOL $1 / 4$ & UGAMS 04137 & $-5,8$ & $\mathrm{M}$ & 2201 & \pm 3 & 35 & $1728 ; 1855$ & $26 \mathrm{AD} ; 285 \mathrm{AD}$ \\
\hline GOL $1 / 10$ & UGAMS 03184 & $-1,68$ & $\mathrm{M}$ & 3347 & \pm 2 & 24 & $3140 ; 3275$ & $1378 \mathrm{BC} ; 1120 \mathrm{BC}$ \\
\hline GOL 1/14 & UGAMS 03185 & $-0,87$ & $\mathrm{M}$ & 4013 & \pm 2 & 24 & $3951 ; 4084$ & $2198 \mathrm{BC} ; 1932 \mathrm{BC}$ \\
\hline GOL 1/22 & UGAMS 03186 & $-1,09$ & $\mathrm{M}$ & 6015 & \pm 2 & 26 & $6370 ; 6483$ & $4588 \mathrm{BC} ; 4355 \mathrm{BC}$ \\
\hline GOL 1/24 & UGAMS 03187 & $-0,62$ & $\mathrm{M}$ & 6722 & & 25 & $7197 ; 7297$ & $5400 \mathrm{BC} ; 5204 \mathrm{BC}$ \\
\hline GOL 2/10 & UGAMS 04140 & 2,06 & $\mathrm{M}$ & 3826 & & 28 & $3699 ; 3830$ & $1945 \mathrm{BC} ; 1686 \mathrm{BC}$ \\
\hline GOL 3/9 & UGAMS 03188 & $-29,24$ & PR & 2673 & & 26 & $2753 ; 2785$ & $895 \mathrm{BC} ; 799 \mathrm{BC}$ \\
\hline GOL 3/11 & UGAMS 03189 & $-3,02$ & $\mathrm{M}$ & 4356 & & 26 & $4415 ; 4535$ & $2685 \mathrm{BC} ; 2421 \mathrm{BC}$ \\
\hline SEM 4/8 & LU 5847 & -27.0 & $\mathrm{PR}$ & 2240 & \pm 1 & 110 & $2354 ; 2067$ & $743 \mathrm{BC} ; 3 \mathrm{AD}$ \\
\hline SEM 4/10 & LU 5846 & -27.4 & $\mathrm{PR}$ & 3830 & & 110 & $4411 ; 4091$ & $2573 \mathrm{BC} ; 1965 \mathrm{BC}$ \\
\hline SEM 4/18 & LU 5831 & -27.0 & $\mathrm{PR}$ & 4540 & \pm 6 & 60 & $5312 ; 5055$ & $3496 \mathrm{BC} ; 3026 \mathrm{BC}$ \\
\hline SEM 4/22 & LU 5848 & -28.5 & PR & 5520 & \pm 1 & 100 & $6411 ; 6208$ & $4582 \mathrm{BC} ; 4055 \mathrm{BC}$ \\
\hline SEM 4/24 & LU 5845 & -25.8 & PR & 6120 & \pm 7 & 70 & $7156 ; 6912$ & $5281 \mathrm{BC} ; 4845 \mathrm{BC}$ \\
\hline SEM 4/25 & LU 5849 & -27.1 & PR & 6220 & \pm 1 & 100 & $7251 ; 7005$ & $5464 \mathrm{BC} ; 4859 \mathrm{BC}$ \\
\hline
\end{tabular}

Table 2 : All ages are calibrated with the calibration software Calib 5.0.2. For marine carbonates the reservoir age of 408 years (Hughen et al. 2004) is applied with delta R of $5 \pm$ 35 years according to Jones \& Gagnon (1994) 


\begin{tabular}{|c|c|c|c|c|c|c|c|}
\hline \multirow{2}{*}{$\begin{array}{l}\text { Sample ID } \\
\text { (depth b.s.l.) }\end{array}$} & \multirow[t]{2}{*}{ Lab no. } & \multirow[t]{2}{*}{ material } & \multicolumn{3}{|c|}{ 14C Age } & \multicolumn{2}{|c|}{ Calibrated ages } \\
\hline & & & & \pm & $1 \mathrm{~s}$ & 1 Sigma max; min (cal BP) & $\begin{array}{l}2 \text { Sigma max; min } \\
\text { (cal BC/AD) }\end{array}$ \\
\hline $\mathrm{S} 2(3.2-3.5)$ & GIN-9934 & $\mathrm{M}(\mathrm{bs})$ & 1130 & \pm & 100 & $782 ; 568$ & $1059 \mathrm{AD} ; 1431 \mathrm{AD}$ \\
\hline $\mathrm{S} 2(3.6-3.8)$ & GIN-9935 & $\mathrm{M}(\mathrm{bs})$ & 1380 & \pm & 90 & $1031 ; 812$ & $812 \mathrm{AD} ; 1235 \mathrm{AD}$ \\
\hline $\mathrm{S} 2(7.8-8.0)$ & GIN-9939 & $\mathrm{M}$ & 2080 & \pm & 200 & $1870 ; 1409$ & $191 \mathrm{BC} ; 716 \mathrm{AD}$ \\
\hline $\mathrm{S} 2(8.1-8.2)$ & GIN-9938 & $\mathrm{M}$ & 2820 & \pm & 110 & $2702 ; 2417$ & $867 \mathrm{BC} ; 339 \mathrm{BC}$ \\
\hline S2 (10-10.3) & GIN-9937 & $\mathrm{M}$ & 3180 & \pm & 290 & $3373 ; 2670$ & $1763 \mathrm{BC} ; 767 \mathrm{BC}$ \\
\hline $\mathrm{S} 3(2.8-3.0)$ & MGU-1504 & $\mathrm{M}(\mathrm{bs})$ & 1260 & \pm & 60 & $877 ; 730$ & $1024 \mathrm{AD} ; 1284 \mathrm{AD}$ \\
\hline $\mathrm{S} 3(4.2-4.5)$ & MGU-1520 & $\mathrm{M}(\mathrm{bs})$ & 3390 & \pm & 150 & $3431 ; 3044$ & $1657 \mathrm{BC} ; 895 \mathrm{BC}$ \\
\hline $\mathrm{S} 3(7.7-8.0)$ & MGU-1502 & $\mathrm{M}(\mathrm{bs})$ & 4700 & \pm & 150 & $5208 ; 4787$ & $3377 \mathrm{BC} ; 2561 \mathrm{BC}$ \\
\hline S3 (9.0-9.3) & MGU-1501 & $\mathrm{M}(\mathrm{bs})$ & 5430 & \pm & 120 & $5917 ; 5647$ & $4165 \mathrm{BC} ; 3607 \mathrm{BC}$ \\
\hline S4 (6.7-7.0) & MGU-1575 & $\mathrm{M}(\mathrm{bs})$ & 1930 & \pm & 60 & $1547 ; 1382$ & $305 \mathrm{AD} ; 637 \mathrm{AD}$ \\
\hline S4 (7.8-8.1) & MGU-1565 & $\mathrm{M}(\mathrm{bs})$ & 2660 & \pm & 60 & $2466 ; 2266$ & $642 \mathrm{BC} ; 196 \mathrm{BC}$ \\
\hline S4 (10-10.3) & MGU-1574 & $\mathrm{M}(\mathrm{bs})$ & 3370 & \pm & 45 & $3317 ; 3162$ & $1418 \mathrm{BC} ; 1114 \mathrm{BC}$ \\
\hline S5 (2.5-3.0) & MGU-1517 & $\mathrm{M}$ & 1595 & \pm & 50 & $1224 ; 1080$ & $678 \mathrm{AD} ; 947 \mathrm{AD}$ \\
\hline S5 (3.0-3.5) & MGU-1529 & $\mathrm{M}$ & 3390 & \pm & 120 & $3390 ; 3075$ & $1599 \mathrm{BC} ; 963 \mathrm{BC}$ \\
\hline S5 (5.5-6.0) & MGU-1516 & $\mathrm{M}$ & 3730 & \pm & 100 & $3804 ; 3528$ & $1968 \mathrm{BC} ; 1437 \mathrm{BC}$ \\
\hline S5 (6.5-7.0) & MGU-1515 & M & 4220 & \pm & 100 & $4437 ; 4144$ & $2643 \mathrm{BC} ; 2035 \mathrm{BC}$ \\
\hline
\end{tabular}

Table 3 : Radiocarbon Dates obtained on mollusc sample $\mathrm{M}(\mathrm{bs})=$ mollusc bulk sample ; $\mathrm{M}=$ mollusc (single valve) at the Geological Institute of the Russian Academy of Sciences (GIN) and at the Geographical Faculty of Moscow State University (MGU). All ages are calibrated with the calibration software Calib 5.0.2. For marine carbonates the reservoir age of 408 years (Hughen et al. 2004) is applied with delta $\mathrm{R}$ of $5 \pm 35$ years according to Jones \& Gagnon (1994) 


\begin{tabular}{|c|c|c|c|c|}
\hline River (gauge station) & $\begin{array}{c}\text { Period of } \\
\text { measurements }\end{array}$ & $\begin{array}{c}\text { Discharge } \\
\text { (av. annual) }\end{array}$ & $\begin{array}{c}\text { Discharge } \\
\text { (av. annual) }\end{array}$ & $\begin{array}{c}\text { Discharge } \\
\text { (av. annual) }\end{array}$ \\
\hline & & $\max \left(\mathrm{m}^{3} / \mathbf{s}\right)$ & $\min \left(\mathbf{m}^{3} / \mathbf{s}\right)$ & mean $\left(\mathbf{m}^{3} / \mathbf{s}\right)$ \\
\hline Danube (Ceatal Izmail, ROM) & $1921-1984$ & $9417.17(1941)$ & $4023.58(1921)$ & 6499.0 \\
\hline Dnieper (Hydroelectr. Plant, UKR) & $1952-1984$ & $2656.33(1970)$ & $800.75(1954)$ & 1482.3 \\
\hline Don (Razdorskaya, RUS) & $1891-1984$ & $1657.42(1942)$ & $300.0(1972)$ & 790.4 \\
\hline Rioni (Sakochakidze, GEO) & $1965-1984$ & $523.83(1978)$ & $309.75(1969)$ & 408.6 \\
\hline Dniester (Bendery, UKR) & $1965-1984$ & $610.0(1980)$ & $234.08(1984)$ & 375.2 \\
\hline Kuban (Tikhovsky, RUS) & $1965-1984$ & $446.83(1968)$ & $186.42(1969)$ & 317.9 \\
\hline Kizilirmak (Inozu, TUR) & $1976-1983$ & $243.67(1981)$ & $171.75(1979)$ & 201.8 \\
\hline Sakarya (Botbasi, TUR) & $1976-1983$ & $481,0(1981)$ & $54.0(1977)$ & 192.3 \\
\hline Southern Bug (Aleksandrovka, UKR) & $1965-1984$ & $198.04(1980)$ & $68.58(1975)$ & 110.3 \\
\hline Total amount $\left(\mathrm{m}^{3} / \mathrm{s}\right)$ & & $16,234.29$ & $6,148.91$ & $10,377.8$ \\
\hline Total amount $\left(\mathrm{km}^{3} /\right.$ year $)$ & & $\underline{511.96}$ & 193.91 & 327.3 \\
\hline
\end{tabular}

Tab. 1: Average annual discharge of the most important rivers that flow into the Black Sea basin with maximum, minimum and mean values. Sources: Vorosmarty et al. 1998; Global River Discharge Database (updated 02/13/2010):

http://www.sage. wisc.edu/riverdata/index.php?qual=32 